\title{
Significant Promotion Effect of Mo Additive on a Novel Ce-Zr Mixed Oxide Catalyst for the Selective Catalytic Reduction of $\mathrm{NO}_{x}$ with $\mathrm{NH}_{3}$
}

\author{
Shipeng Ding, Fudong Liu, ${ }^{* \dagger}$ Xiaoyan Shi, Kuo Liu, Zhihua Lian, Lijuan Xie, and Hong He*
}

State Key Joint Laboratory of Environment Simulation and Pollution Control, Research Center for Eco-Environmental Sciences, Chinese Academy of Sciences, 18 Shuangqing Road, Haidian District, Beijing 100085, P. R. China

\section{Supporting Information}

ABSTRACT: A novel Mo-promoted $\mathrm{Ce}-\mathrm{Zr}$ mixed oxide catalyst prepared by a homogeneous precipitation method was used for the selective catalytic reduction (SCR) of $\mathrm{NO}_{x}$ with $\mathrm{NH}_{3}$. The optimal catalyst showed high $\mathrm{NH}_{3}$-SCR activity, $\mathrm{SO}_{2} / \mathrm{H}_{2} \mathrm{O}$ durability, and thermal stability under test conditions. The addition of Mo inhibited growth of the $\mathrm{CeO}_{2}$ particle size, improved the redox ability, and increased the amount of surface acidity, especially the Lewis acidity, all of which were favorable for the excellent $\mathrm{NH}_{3}$-SCR performance. It is believed that the catalyst is promising for the removal of $\mathrm{NO}_{x}$ from diesel engine exhaust.
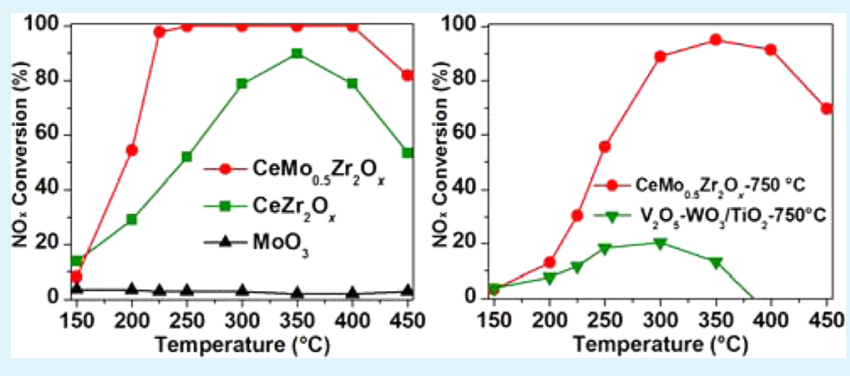

KEYWORDS: selective catalytic reduction, nitrogen oxides, diesel engine exhaust, thermal stability, Ce-Zr mixed oxide

\section{INTRODUCTION}

Nitrogen oxides $\left(\mathrm{NO}_{x}\right)$ emitted from stationary and mobile sources have been major atmospheric pollutants. The selective catalytic reduction (SCR) of $\mathrm{NO}_{x}$ with $\mathrm{NH}_{3}$ or urea has been extensively studied as one of the most effective methods to remove $\mathrm{NO}_{x}$, and the most widely used commercial catalyst is $\mathrm{V}_{2} \mathrm{O}_{5}-\mathrm{WO}_{3} / \mathrm{TiO}_{2} \cdot{ }^{1-4}$ However, there are still some inevitable disadvantages with this catalyst system, such as the toxicity of vanadium pentoxide, narrow operation temperature window, and high conversion of $\mathrm{SO}_{2}$ to $\mathrm{SO}_{3}$ at high temperature. ${ }^{5}$ Therefore, it is desirable to develop a novel $\mathrm{NH}_{3}$-SCR catalyst that can substitute for the conventional V-based catalyst in recent years.

Cerium oxide $\left(\mathrm{CeO}_{2}\right)$ as one of the most abundant rare-earth oxides has attracted much interest over the past decades in many catalytic reactions such as carbon monoxide oxidation, water-gas shift, nitric oxide reduction, and reforming reactions. ${ }^{6-8}$ However, pure $\mathrm{CeO}_{2}$ shows poor thermal stability and is susceptible sintering at high temperature. ${ }^{9}$ It has been reported that the addition of $\mathrm{ZrO}_{2}$ to $\mathrm{CeO}_{2}$ leads to improvement in the oxygen storage capacity and thermal stability. ${ }^{10,11} \mathrm{Ce}-\mathrm{Zr}$ mixed oxide combines the highly refractory property of $\mathrm{ZrO}_{2}$ with the oxygen storage capacity of $\mathrm{CeO}_{2}$, which can be used as a catalyst or support for $\mathrm{NH}_{3}-$ SCR of $\mathrm{NO}_{x}$. It was found that nickel and sulfate modification increased the strength of Lewis acid sites and enhanced the $\mathrm{NH}_{3}$ adsorption capacity, all of which were beneficial for improvement of the activity and selectivity of $\mathrm{Ce}-\mathrm{Zr}$ catalyst. ${ }^{12}$ It was also believed that $\mathrm{NiO}$ on the $\mathrm{CeO}_{2}$ nanorods played an important role for enhancement of the $\mathrm{NH}_{3}$-SCR activity because of the higher concentration of $\mathrm{Ce}^{3+}$, larger amount of active $\mathrm{O}_{\alpha}$, lower amount of energy required for oxygen vacancy distortion, and strong interaction between $\mathrm{NO}$ and $\mathrm{NH}_{3}{ }^{13}$ The experimental and kinetic model results indicated that the $\mathrm{MnO}_{x}(0.6) / \mathrm{Ce}_{0.5} \mathrm{Zr}_{0.5} \mathrm{O}_{2}$ catalyst showed high $\mathrm{NO}$ conversion and $\mathrm{N}_{2}$ selectivity at low temperatures, and the apparent activation energy of the $\mathrm{NH}_{3}-\mathrm{SCR}$ reaction on $\mathrm{MnO}_{x}(0.6) /$ $\mathrm{Ce}_{0.5} \mathrm{Zr}_{0.5} \mathrm{O}_{2}(18 \mathrm{~kJ} / \mathrm{mol})$ was lower than that on $\mathrm{MnO}_{x} / \mathrm{TiO}_{2}$ $(38 \mathrm{~kJ} / \mathrm{mol}) .{ }^{14} \mathrm{~A} \mathrm{WO}_{3} / \mathrm{CeO}_{2}-\mathrm{ZrO}_{2}$ catalyst annealed in air at $800{ }^{\circ} \mathrm{C}$ for $1 \mathrm{~h}$ still showed high $\mathrm{NH}_{3}$-SCR activity. ${ }^{15}$ The three-dimensional ordered macroporous (3DOM) $\mathrm{Ce}_{0.75} \mathrm{Zr}_{0.2} \mathrm{M}_{0.05} \mathrm{O}_{2-\delta}(\mathrm{M}=\mathrm{Fe}, \mathrm{Mn}, \mathrm{Co})$ synthesized by a colloidal template method also exhibited good activity for $\mathrm{NH}_{3}$ SCR of $\mathrm{NO}_{x}$; the characterization results showed that the dopants were effectively doped into the $\mathrm{Ce}-\mathrm{Zr}$ oxide solid solution and a strong synergistic effect existed between the dopants and $\mathrm{Ce}-\mathrm{Zr}$ oxide, all of which were beneficial for improvement of the $\mathrm{NH}_{3}$-SCR activity. ${ }^{16}$ It was also found that the morphology of $\mathrm{CeZrO}_{x}$ had a remarkable effect on the performance of the $\mathrm{MnO}_{x} / \mathrm{CeO}_{2}-\mathrm{ZrO}_{2}$ catalyst for the $\mathrm{NH}_{3}-$ SCR reaction, and $\mathrm{MnO}_{x} / \mathrm{CeO}_{2}-\mathrm{ZrO}_{2}$ nanorods showed activity superior to that of nanotubes and nanopolyhedra. ${ }^{17}$ $\mathrm{Ce}_{0.75} \mathrm{Zr}_{0.25} \mathrm{O}_{2}-\mathrm{PO}_{4}{ }^{3-}$ catalyst prepared by impregnating phosphates on $\mathrm{Ce}_{0.75} \mathrm{Zr}_{0.25} \mathrm{O}_{2}$ still presented high SCR activity at $300-400{ }^{\circ} \mathrm{C}$ after hydrothermal aging at $760{ }^{\circ} \mathrm{C}$ for $48 \mathrm{~h}$, which might result from the fact that phosphates improved $\mathrm{NH}_{3}$ adsorption and suppressed the unselective oxidation of $\mathrm{NH}_{3}$ at high temperatures. ${ }^{18}$ Although catalysts containing $\mathrm{CeO}_{2}-\mathrm{ZrO}_{2}$ oxide, such as $\mathrm{WO}_{3} / \mathrm{CeO}_{2}-\mathrm{ZrO}_{2}{ }^{15}, \mathrm{MnO}_{x}$ / $\mathrm{Ce}_{0.5} \mathrm{Zr}_{0.5} \mathrm{O}_{2}{ }^{14}, \mathrm{Ce}_{0.75} \mathrm{Zr}_{0.25} \mathrm{O}_{2}-\mathrm{PO}_{4}{ }^{3-}$ and Ni-modified $\mathrm{Ce}-\mathrm{Zr}$

Received: January 21, 2015

Accepted: April 20, 2015

Published: April 20, 2015 
oxide, ${ }^{18}$ have been used toward $\mathrm{NH}_{3}$-SCR of $\mathrm{NO}$ in recent years, the promotional effect of Mo addition on the $\mathrm{NH}_{3}$-SCR activity over $\mathrm{CeO}_{2}-\mathrm{ZrO}_{2}$ and the thermal stability of $\mathrm{CeMo}_{0.5} \mathrm{Zr}_{2} \mathrm{O}_{x}$ catalyst have never been investigated in recent publications. In addition, $\mathrm{MoO}_{3}$ is widely used as a stabilizer and a promoter to improve the activity, mechanical, and structural properties of a $\mathrm{V}_{2} \mathrm{O}_{5} / \mathrm{TiO}_{2}$ catalyst for $\mathrm{NH}_{3}$-SCR prcocess. ${ }^{19-21}$ It was also found that the addition of $\mathrm{MoO}_{3}$ promoted the adsorption and activation of $\mathrm{NH}_{3}$, which was conducive to improvement of the $\mathrm{NH}_{3}$-SCR activity of a $\mathrm{MoO}_{3}$-doped $\mathrm{Ce} / \mathrm{TiO}_{2}$ catalyst. $^{22}$

In order to take full advantage of the high $\mathrm{NH}_{3}-\mathrm{SCR}$ activity and thermal stability of $\mathrm{Ce}-\mathrm{Zr}$ mixed oxide and promoting effect of $\mathrm{MoO}_{3}$, in the present work, a series of novel Mopromoted $\mathrm{Ce}-\mathrm{Zr}$ catalysts was prepared by a homogeneous precipitation method and were applied to $\mathrm{NH}_{3}-\mathrm{SCR}$ of $\mathrm{NO}_{x}$. The catalyst showed high SCR activity, $\mathrm{SO}_{2} / \mathrm{H}_{2} \mathrm{O}$ durability, and thermal stability under test conditions. The structure, redox ability, and acidity of the catalyst were characterized using different techniques. The promotional effect of Mo species and the $\mathrm{NH}_{3}$-SCR reaction mechanism over the catalyst were fully discussed. The catalyst is quite promising for $\mathrm{NO}_{x}$ emission control from diesel engine exhaust.

\section{EXPERIMENTAL SECTION}

2.1. Catalyst Preparation and Activity Test. The catalysts were prepared by a novel and facile homogeneous precipitation method using urea as the precipitator. ${ }^{23}$ All chemicals used were of analytical grade. The aqueous solution of $\mathrm{Ce}\left(\mathrm{NO}_{3}\right)_{3} \cdot 6 \mathrm{H}_{2} \mathrm{O}, \mathrm{Zr}\left(\mathrm{NO}_{3}\right)_{4} \cdot 5 \mathrm{H}_{2} \mathrm{O}$, and $\left(\mathrm{NH}_{4}\right)_{6} \mathrm{Mo}_{7} \mathrm{O}_{24} \cdot 4 \mathrm{H}_{2} \mathrm{O}$ was mixed with the required molar ratio. An excessive urea aqueous solution was then added to the mixed solution. The solution was heated to $90{ }^{\circ} \mathrm{C}$ and continuously stirred for $12 \mathrm{~h}$. The $\mathrm{pH}$ variation of the mixed solution during the homogeneous precipitation process is shown in Figure S1 in the Supporting Information (SI). The initial $\mathrm{pH}$ of the mixed solution, which was measured by a $\mathrm{pH}$ meter (Sartorius $\mathrm{PB}-10$ ), was about 1.0 because of hydrolysis of the precursors. However, as the preparation time increased from 1.0 to $4.0 \mathrm{~h}$, a substantial amount of precipitate was formed and the $\mathrm{pH}$ was greatly increased from 1.0 to 7.0 probably because of the decomposition of urea. After filtration and washing with deionized water, the resulting precipitate was dried at $100{ }^{\circ} \mathrm{C}$ overnight and subsequently calcined at $500{ }^{\circ} \mathrm{C}$ for $3 \mathrm{~h}$ in air. The bulk molar ratios of Ce:Mo: $\mathrm{Zr}$ in the $\mathrm{CeMo}_{a} \mathrm{Zr}_{2} \mathrm{O}_{x}$ series of catalysts were analyzed by an inductively coupled plasma instrument (OPTMIA 2000DV). As shown in Table S1 in the SI, the actual proportions of $\mathrm{Ce}: \mathrm{Mo}: \mathrm{Zr}$ in the bulk were not consistent with the designed ones, indicating that not all of the ions precipitated in the process of homogeneous precipitation. In addition, the distribution of $\mathrm{Zr}, \mathrm{Ce}$, and Mo derived from scanning electron microscopy-energy-dispersive Xray (SEM-EDX; Hitachi S-3000N) over $\mathrm{CeMo}_{0.5} \mathrm{Zr}_{2} \mathrm{O}_{x}$ catalyst prepared by homogeneous precipitation was presented in Figure S2 in the SI. Zr exhibited a slightly poor dispersion; however, the Ce and Mo species were homogeneously dispersed on the surface of the catalyst. The catalysts were also calcined at desired temperatures $(500$, $550,600,650,700$, and $750{ }^{\circ} \mathrm{C}$ ) for $8 \mathrm{~h}$ to test the thermal stability. In addition, the $\mathrm{CeMo}_{0.5} \mathrm{Zr}_{2} \mathrm{O}_{x}$ catalysts were also hydrothermally aged at 700 and $760{ }^{\circ} \mathrm{C}$ for $48 \mathrm{~h}$ to evaluate the hydrothermal stability. The calcined samples were crushed and sieved to 40-60 mesh for the activity test. The catalysts were denoted as $\mathrm{CeMo}_{a} \mathrm{Zr}_{b} \mathrm{O}_{x}$, where $a(a=$ $0,0.1,0.5,1.0,1.5)$ represented the molar ratio of Mo:Ce and $b(b=$ $0.5,1.0,2.0,4.0)$ indicated the molar ratio of $\mathrm{Zr}: \mathrm{Ce}$. The $\mathrm{CeMo}_{0.5} \mathrm{Zr}_{2} \mathrm{O}_{x}$ catalysts calcined at different temperatures for $8 \mathrm{~h}$ were denoted as $\mathrm{CeMo}_{0.5} \mathrm{Zr}_{2} \mathrm{O}_{x}$-t , where $t$ represented the calcination temperature in degrees Celsius. For comparison, a conventional $\mathrm{V}_{2} \mathrm{O}_{5}-\mathrm{WO}_{3} / \mathrm{TiO}_{2}$ catalyst with 3 wt $\%$ (or 1 wt $\%$ ) $\mathrm{V}_{2} \mathrm{O}_{5}$ and 10 wt $\%$ $\mathrm{WO}_{3}$ was also prepared using the conventional impregnation method. $\mathrm{NH}_{4} \mathrm{VO}_{3}$ and $\left(\mathrm{NH}_{4}\right)_{10} \mathrm{~W}_{12} \mathrm{O}_{41}$ were used as sources of $\mathrm{V}$ and $\mathrm{W}$, respectively. After impregnation, the excess $\mathrm{H}_{2} \mathrm{O}$ was removed in a rotary evaporator at $60^{\circ} \mathrm{C}$. The sample was dried at $100{ }^{\circ} \mathrm{C}$ overnight and subsequently calcined at desired temperatures for $8 \mathrm{~h}$ in air.

The $\mathrm{NH}_{3}-\mathrm{SCR}$ activity tests were carried out in a fixed-bed quartz tube reactor at atmospheric pressure. The weights of the catalysts employed were $1.10 \mathrm{~g}$ of $\mathrm{CeZr}_{2} \mathrm{O}_{x}, 0.95 \mathrm{~g}$ of $\mathrm{CeMo}_{0.1} \mathrm{Zr}_{2} \mathrm{O}_{x}, 0.75 \mathrm{~g}$ of $\mathrm{CeMo}_{0.5} \mathrm{Zr}_{2} \mathrm{O}_{x}, 0.67 \mathrm{~g}$ of $\mathrm{CeMo}_{1.0} \mathrm{Zr}_{2} \mathrm{O}_{x}$, and $0.56 \mathrm{~g}$ of $\mathrm{CeMo}_{1.5} \mathrm{Zr}_{2} \mathrm{O}_{x}$ to maintain the gas hourly space velocity (GHSV) at $50000 \mathrm{~h}^{-1}$ over various catalysts. The reaction gas contained $500 \mathrm{ppm}$ of $\mathrm{NO}$ (or $\left.[\mathrm{NO}]=250 \mathrm{ppm} ;\left[\mathrm{NO}_{2}\right]=250 \mathrm{ppm}\right), 500 \mathrm{ppm}$ of $\mathrm{NH}_{3}, 5 \mathrm{vol} \% \mathrm{O}_{2}$, $\mathrm{N}_{2}$ balance, and $500 \mathrm{~mL} / \mathrm{min}$ flow rate. Furthermore, 5 vol \% $\mathrm{H}_{2} \mathrm{O}$ or $100 \mathrm{ppm}$ of $\mathrm{SO}_{2}$ (or $500 \mathrm{ppm}$ of $\mathrm{SO}_{2}$ ) was introduced to the reaction gas to test the poisoning effect of $\mathrm{H}_{2} \mathrm{O} / \mathrm{SO}_{2}$ on $\mathrm{NO}_{x}$ conversion over the $\mathrm{CeMo}_{0.5} \mathrm{Zr}_{2} \mathrm{O}_{x}$ catalyst. The effluent gas was continuously analyzed by a Fourier transform infrared (FTIR) spectrometer (Nicolet Nexus $670)$ equipped with a heated, low-volume multiple-path gas cell $(2 \mathrm{~m})$. The FTIR spectra were collected after $1 \mathrm{~h}$ when the SCR reaction reached a steady state. $\mathrm{NO}_{x}$ conversion and $\mathrm{N}_{2}$ selectivity were calculated as follows:

$$
\begin{aligned}
\mathrm{NO}_{x} \text { conversion } & =\left(1-\frac{[\mathrm{NO}]_{\text {out }}+\left[\mathrm{NO}_{2}\right]_{\text {out }}}{[\mathrm{NO}]_{\text {in }}+\left[\mathrm{NO}_{2}\right]_{\text {in }}}\right) \times 100 \% \\
\mathrm{~N}_{2} \text { selectivity }= & \frac{[\mathrm{NO}]_{\text {in }}+\left[\mathrm{NH}_{3}\right]_{\text {in }}-\left[\mathrm{NO}_{2}\right]_{\text {out }}-2\left[\mathrm{~N}_{2} \mathrm{O}\right]_{\text {out }}}{[\mathrm{NO}]_{\text {in }}+\left[\mathrm{NH}_{3}\right]_{\text {in }}} \\
& \times 100 \%
\end{aligned}
$$

2.2. Characterization. The $\mathrm{N}_{2}$ adsorption-desorption isotherms over catalysts were obtained at $77 \mathrm{~K}$ using a Quantachrome Autosorb$1 \mathrm{C}$ instrument. Prior to $\mathrm{N}_{2}$ physisorption, all samples were degassed in a vacuum at $300{ }^{\circ} \mathrm{C}$ for $5 \mathrm{~h}$. The surface areas were determined by a Brunauer-Emmett-Teller (BET) equation in the 0.05-0.35 partial pressure range. Pore volumes were determined by the BarrettJoyner-Halenda $(\mathrm{BJH})$ method from the desorption branches of the isotherms.

Powder X-ray diffraction (XRD) measurements of the catalysts were carried out on a computerized PANalytical X'Pert Pro diffractometer with $\mathrm{Cu} \mathrm{K} \alpha(\lambda=0.15406 \mathrm{~nm})$ radiation. The data of $2 \theta$ from 20 to $80^{\circ}$ were collected at $8^{\circ} / \mathrm{min}$ with a step size of $0.07^{\circ}$.

Visible Raman spectra of the catalysts were collected at room temperature on a Spex $1877 \mathrm{D}$ Triplemate spectrograph with a spectral resolution of $2 \mathrm{~cm}^{-1}$. A $532 \mathrm{~nm}$ diode-pumped solid-state semiconductor laser was used as the excitation source with a power output of $30 \mathrm{~mW}$. The time for recording each spectrum was $10 \mathrm{~s}$.

The $\mathrm{H}_{2}$-TPR (temperature-programmed reduction) experiments were carried out on a Micromeritics AutoChem 2920 chemisorption analyzer. In a typical measurement, $100 \mathrm{mg}$ of the catalyst was first pretreated in a flow of $20 \mathrm{vol} \% \mathrm{O}_{2} / \mathrm{N}_{2}(50 \mathrm{~mL} / \mathrm{min})$ at $400{ }^{\circ} \mathrm{C}$ for 0.5 $\mathrm{h}$ and then cooled to the room temperature $\left(30^{\circ} \mathrm{C}\right)$ followed by $\mathrm{Ar}$ purging for $0.5 \mathrm{~h}$. Then the temperature was linearly raised at $10{ }^{\circ} \mathrm{C} /$ min from 30 to $700{ }^{\circ} \mathrm{C}$ in a flow of $10 \mathrm{vol} \% \mathrm{H}_{2} / \mathrm{Ar}(30 \mathrm{~mL} / \mathrm{min}) . \mathrm{H}_{2}$ consumption was monitored by a thermal conductivity detector.

$\mathrm{NH}_{3}$-TPD (temperature-programmed decomposition) together with NO-TPD was also conducted on a Micromeritics AutoChem 2920 chemisorption analyzer, equipped with a quadrupole mass spectrometer (MKS Cirrus) to monitor the signals of $\mathrm{NH}_{3}(\mathrm{~m} / z$ 17) and NO $(\mathrm{m} / z$ 30). Prior to TPD experiments, the $100 \mathrm{mg}$ samples were pretreated at $400{ }^{\circ} \mathrm{C}$ in a flow of $20 \mathrm{vol} \% \mathrm{O}_{2} / \mathrm{N}_{2}$ for $0.5 \mathrm{~h}$ and cooled to room temperature. Then the samples were exposed to a flow of $\mathrm{NH}_{3}$ or $\mathrm{NO}+\mathrm{O}_{2}$ for $1.0 \mathrm{~h}$. Finally, the temperature was raised to $600{ }^{\circ} \mathrm{C}$ in an Ar flow at the rate of $10{ }^{\circ} \mathrm{C} / \mathrm{min}$.

The in situ diffuse-reflectance infrared Fourier transform spectroscopy (DRIFTS) experiments were carried out on an FTIR spectrometer (Nicolet Nexus 670) equipped with a smart collector and an MCT/A detector cooled by liquid nitrogen. Prior to each experiment, the sample was pretreated at $400{ }^{\circ} \mathrm{C}$ for $0.5 \mathrm{~h}$ in $20 \mathrm{vol} \%$ $\mathrm{O}_{2} / \mathrm{N}_{2}$ and then cooled to $200{ }^{\circ} \mathrm{C}$. The background spectrum was collected in flowing $\mathrm{N}_{2}$ and automatically subtracted from the sample spectrum. The reaction conditions were as follows: $500 \mathrm{ppm}$ of $\mathrm{NH}_{3}$, 
$500 \mathrm{ppm}$ of $\mathrm{NO}, 5 \mathrm{vol} \% \mathrm{O}_{2}, \mathrm{~N}_{2}$ balance, and $200 \mathrm{~mL} / \mathrm{min}$ flow rate. All spectra were recorded by accumulating 100 scans with a resolution of $4 \mathrm{~cm}^{-1}$.

\section{RESULTS AND DISCUSSION}

3.1. $\mathrm{NH}_{3}-\mathrm{SCR}$ Activity. Prior to investigation of the $\mathrm{CeMo}_{a} \mathrm{Zr}_{b} \mathrm{O}_{x}$ catalyst, the effect of the Ce: $\mathrm{Zr}$ molar ratio on the SCR activity over the $\mathrm{CeZrO}_{x}$ series of catalysts was systematically investigated, and the results are illustrated in Figure S3 in the SI. It was found that the $\mathrm{CeZr}_{2} \mathrm{O}_{x}$ catalyst, with a Ce:Zr molar ratio of $1: 2$, showed the best $\mathrm{NO}_{x}$ conversion. Therefore, in the later work, the Ce:Zr molar ratio was fixed at 1:2. Figure 1 shows the $\mathrm{NO}_{x}$ conversion and $\mathrm{N}_{2}$ selectivity as a

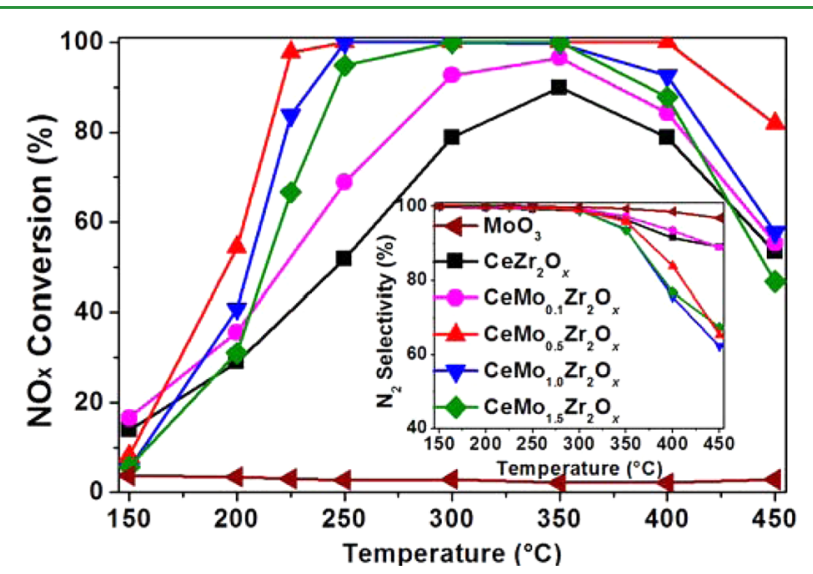

Figure 1. $\mathrm{NO}_{x}$ conversion and $\mathrm{N}_{2}$ selectivity (inserted) in the $\mathrm{NH}_{3}$ SCR reaction as a function of the temperature over pure $\mathrm{MoO}_{3}$ and $\mathrm{CeMo}_{a} \mathrm{Zr}_{2} \mathrm{O}_{x}(a=0,0.1,0.5,1.0,1.5)$ catalysts. Reaction conditions: $[\mathrm{NO}]=\left[\mathrm{NH}_{3}\right]=500 \mathrm{ppm},\left[\mathrm{O}_{2}\right]=5 \mathrm{vol} \%$, and GHSV $=50000 \mathrm{~h}^{-1}$.

function of the temperature in the $\mathrm{NH}_{3}$-SCR reaction over pure $\mathrm{MoO}_{3}$ and $\mathrm{CeMo}_{a} \mathrm{Zr}_{2} \mathrm{O}_{x}$ catalysts under a GHSV of $50000 \mathrm{~h}^{-1}$. $\mathrm{CeZr}_{2} \mathrm{O}_{x}$ exhibited a narrow operation temperature window, and the maximum $\mathrm{NO}_{x}$ conversion was only $90 \%$ at $350{ }^{\circ} \mathrm{C}$. However, the addition of a small amount of Mo (Mo: $\mathrm{Ce}=$ $0.1: 1)$ to $\mathrm{CeZr}_{2} \mathrm{O}_{x}$ led to an obvious enhancement of the $\mathrm{NO}_{x}$ conversion, implying that the coexistence of $\mathrm{Mo}$ and $\mathrm{CeZr}_{2} \mathrm{O}_{x}$ species was very important for promotion of the SCR activity. $\mathrm{CeMo}_{0.5} \mathrm{Zr}_{2} \mathrm{O}_{x}$ with a molar ratio of Mo: $\mathrm{Ce}=0.5: 1$ showed the best $\mathrm{NH}_{3}$-SCR activity and the widest operation temperature window, over which $100 \%$ of $\mathrm{NO}_{x}$ conversion was obtained in a wide temperature range $\left(250-400{ }^{\circ} \mathrm{C}\right)$. Further increasing the Mo:Ce molar ratios to $1: 1$ and 1.5:1 resulted in a decline of the $\mathrm{NO}_{x}$ conversion at both low and high temperatures, which was probably due to the decrease of active Ce sites on the catalyst surface. Similar results were also proposed by Shan et al. ${ }^{24}$ and $\mathrm{Li}$ et al. $^{25}$ when investigating the $\mathrm{CeO}_{2}-\mathrm{WO}_{3}$ and $\mathrm{CeO}_{2}-$ $\mathrm{MoO}_{3}$ catalysts. Pure $\mathrm{MoO}_{3}$ showed negligible activity in the whole temperature range, indicating that the Mo species played the role of only the catalyst promoter rather than the active center for the $\mathrm{NH}_{3}-\mathrm{SCR}$ reaction. Although the addition of $\mathrm{MoO}_{3}$ to the $\mathrm{Ce}-\mathrm{Zr}$ catalyst could decrease the $\mathrm{N}_{2}$ selectivity slightly owing to the production of $\mathrm{N}_{2} \mathrm{O}$, the $\mathrm{N}_{2}$ selectivity over $\mathrm{CeMo}_{0.5} \mathrm{Zr}_{2} \mathrm{O}_{x}$ was still more than $80 \%$ below $400{ }^{\circ} \mathrm{C}$. The $\mathrm{NH}_{3}$-SCR results show that some synergistic effects possibly exist between $\mathrm{Mo}$ and $\mathrm{Ce}-\mathrm{Zr}$ species, which will be discussed later in this work.

In addition, the catalytic activity over $\mathrm{CeMo}_{0.5} \mathrm{Zr}_{b} \mathrm{O}_{x}$ with various $\mathrm{Zr}$ :Ce molar ratios is presented in Figure S4 in the SI. It was obvious that the $\mathrm{NO}_{x}$ conversions over $\mathrm{CeMo}_{0.5} \mathrm{Zr}_{1} \mathrm{O}_{x}$ and $\mathrm{CeMo}_{0.5} \mathrm{Zr}_{2} \mathrm{O}_{x}$ were similar and higher than those over $\mathrm{CeMo}_{0.5} \mathrm{Zr}_{0.5} \mathrm{O}_{x}$ and $\mathrm{CeMo}_{0.5} \mathrm{Zr}_{4} \mathrm{O}_{x}$ below $300{ }^{\circ} \mathrm{C}$. However, $\mathrm{CeMo}_{0.5} \mathrm{Zr}_{2} \mathrm{O}_{x}$ showed better $\mathrm{NH}_{3}$-SCR activity than Ce$\mathrm{Mo}_{0.5} \mathrm{Zr}_{1} \mathrm{O}_{x}$ above $350{ }^{\circ} \mathrm{C}$. Therefore, in the following studies, $\mathrm{CeMo}_{0.5} \mathrm{Zr}_{2} \mathrm{O}_{x}$ was chosen to investigate the "fast SCR" effect and $\mathrm{SO}_{2} / \mathrm{H}_{2} \mathrm{O}$ resistance together with the thermal durability of the Mo-containing catalyst.

It was clear that when $\mathrm{NO}_{2}\left(\mathrm{NO}_{2}: \mathrm{NO}=1: 1\right)$ was introduced to the reaction gas, the $\mathrm{NO}_{x}$ conversion over $\mathrm{CeMo}_{0.5} \mathrm{Zr}_{2} \mathrm{O}_{x}$ at low temperatures was greatly improved because of the "fast SCR" effect and the $\mathrm{NO}_{x}$ conversion was as high as $100 \%$ in a wide temperature range from 150 to $400{ }^{\circ} \mathrm{C}$; see Figure S5 in the SI. Therefore, in practical applications, the diesel oxidation catalyst usually is placed in the upstream of the SCR catalyst to convert some $\mathrm{NO}$ to $\mathrm{NO}_{2}$, which has a significant advantage on $\mathrm{NO}_{x}$ removal. To better evaluate the performance of the $\mathrm{CeMo}_{0.5} \mathrm{Zr}_{2} \mathrm{O}_{x}$ catalyst, the $\mathrm{NH}_{3}$-SCR activity over the commercial $\mathrm{V}_{2} \mathrm{O}_{5}(1)-\mathrm{WO}_{3}(10) / \mathrm{TiO}_{2}$ catalyst was also conducted and the results are shown in Figure S6 in the SI. NO conversion over the $\mathrm{CeMo}_{0.5} \mathrm{Zr}_{2} \mathrm{O}_{x}$ catalyst was higher than that over $\mathrm{V}_{2} \mathrm{O}_{5}(1)-\mathrm{WO}_{3}(10) / \mathrm{TiO}_{2}$ even though the $\mathrm{CeMo}_{0.5} \mathrm{Zr}_{2} \mathrm{O}_{x}$ sample exhibited a relatively low $\mathrm{N}_{2}$ selectivity at 400 and 450 ${ }^{\circ} \mathrm{C}$.

3.2. Effect of $\mathrm{SO}_{2}$ and $\mathrm{H}_{2} \mathrm{O}$. The combustion exhaust often contains some $\mathrm{SO}_{2}$ and $\mathrm{H}_{2} \mathrm{O}$ vapor in the practical application, which may lead to deactivation of the SCR catalyst. ${ }^{26}$ Therefore, it is important to investigate the effect of $\mathrm{SO}_{2}$ and $\mathrm{H}_{2} \mathrm{O}$ on the SCR activity. In this work, we studied the effect of $100 \mathrm{ppm}$ of $\mathrm{SO}_{2}$ and $5 \mathrm{vol} \% \mathrm{H}_{2} \mathrm{O}$ on the $\mathrm{NO}_{x}$ conversion over $\mathrm{CeMo}_{0.5} \mathrm{Zr}_{2} \mathrm{O}_{x}$ at $250{ }^{\circ} \mathrm{C}$ under a GHSV of $50000 \mathrm{~h}^{-1}$. As shown in Figure 2A, the introduction of $100 \mathrm{ppm}$ of $\mathrm{SO}_{2}$ into

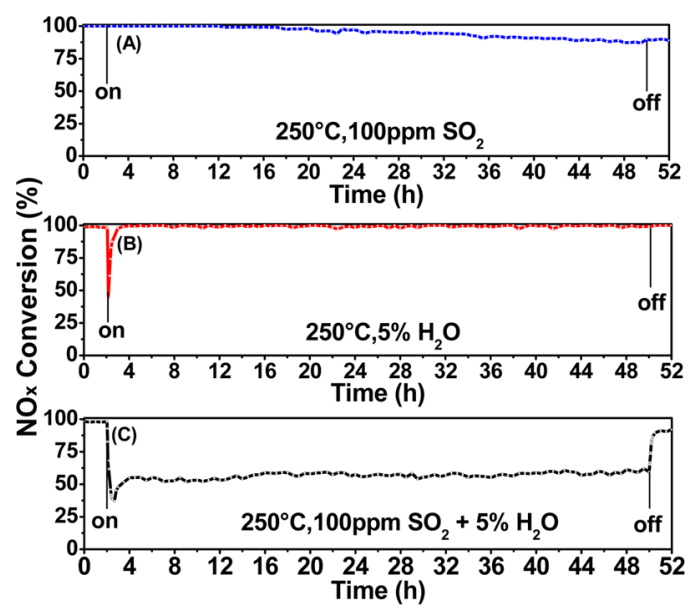

Figure 2. Effect of $\mathrm{SO}_{2}$ (A), $\mathrm{H}_{2} \mathrm{O}(\mathrm{B})$, and $\mathrm{SO}_{2}+\mathrm{H}_{2} \mathrm{O}(\mathrm{C})$ on the SCR activity over the $\mathrm{CeMo}_{0.5} \mathrm{Zr}_{2} \mathrm{O}_{x}$ catalyst at $250{ }^{\circ} \mathrm{C}$. Reaction conditions: $[\mathrm{NO}]=\left[\mathrm{NH}_{3}\right]=500 \mathrm{ppm},\left[\mathrm{O}_{2}\right]=5 \mathrm{vol} \%,\left[\mathrm{SO}_{2}\right]=100$ ppm, $\left[\mathrm{H}_{2} \mathrm{O}\right]=5 \mathrm{vol} \%$, and GHSV $=50000 \mathrm{~h}^{-1}$.

the reaction atmosphere did not result in any decrease of the $\mathrm{NO}_{x}$ conversion for the first $14 \mathrm{~h}$. With the time increasing, the $\mathrm{NO}_{x}$ conversion showed a slow decrease, which might be associated with the deposition of ammonium sulfate/bisulfate on the surface and blockage of the active sites. However, the conversion was still more than $90 \%$ during the measured period. The result in Figure $2 \mathrm{~B}$ showed that when 5 vol $\% \mathrm{H}_{2} \mathrm{O}$ was added to the feed stream, the $\mathrm{NO}_{x}$ conversion dramatically decreased from the initial $100 \%$ to $40 \%$ in the first $2 \mathrm{~h}$ and then 
recovered to $100 \%$. It was believed that the deactivation effect of $\mathrm{H}_{2} \mathrm{O}$ on the activity over catalysts required a long time to achieve steady state. Therefore, when $\mathrm{H}_{2} \mathrm{O}$ vapor was first added into the reaction atmosphere, because of the competitive adsorption between $\mathrm{H}_{2} \mathrm{O}$ and $\mathrm{NH}_{3} / \mathrm{NO}$ over the catalyst, a large amount of $\mathrm{H}_{2} \mathrm{O}$ was adsorbed on the active sites where the $\mathrm{NH}_{3} / \mathrm{NO}$ adsorbed and activated, leading to a decline of the $\mathrm{NO}_{x}$ conversion. However, when the reaction reached steady state $2 \mathrm{~h}$ later, the desorption of excess $\mathrm{H}_{2} \mathrm{O}$ adsorbed on the catalyst made it possible for adsorption and activation of $\mathrm{NH}_{3} / \mathrm{NO}$ on the active sites, which was responsible for the increase of the $\mathrm{NO}_{x}$ conversion. As presented in Figure 2C, when both $100 \mathrm{ppm}$ of $\mathrm{SO}_{2}$ and 5 vol $\% \mathrm{H}_{2} \mathrm{O}$ were introduced, the $\mathrm{NO}_{x}$ conversion also showed a relatively significant decrease to $35 \%$ and then maintained nearly 50\%; after the $\mathrm{SO}_{2}$ and $\mathrm{H}_{2} \mathrm{O}$ inlets were cut off, the activity was rapidly restored to $90 \%$. In short summary, $\mathrm{SO}_{2}$ or $\mathrm{H}_{2} \mathrm{O}$ alone just showed a negligible influence on the SCR activity; the coexistence of $\mathrm{SO}_{2}$ and $\mathrm{H}_{2} \mathrm{O}$ decreased the conversion significantly, indicating that some synergistic inhibition effect between $\mathrm{SO}_{2}$ and $\mathrm{H}_{2} \mathrm{O}$ was present on the SCR activity; however, the effect was reversible to a certain extent. It was believed that when both $\mathrm{SO}_{2}$ and $\mathrm{H}_{2} \mathrm{O}$ were introduced to the reaction atmosphere, the deactivation effect might be not only related to the competitive adsorption between $\mathrm{H}_{2} \mathrm{O}$ and $\mathrm{NH}_{3}$ / $\mathrm{NO}_{x}$ but also associated with the formation of ammonium sulfate together with high thermally stable $\mathrm{Ce}\left(\mathrm{SO}_{4}\right)_{2} /$ $\mathrm{Ce}_{2}\left(\mathrm{SO}_{4}\right)_{3}$ on the active sites because of $\mathrm{SO}_{2}$, which suggested that both $\mathrm{H}_{2} \mathrm{O}$ and $\mathrm{SO}_{2}$ could inhibit the adsorption and activation of $\mathrm{NH}_{3} / \mathrm{NO}_{x}$ on the active sites, leading to an obvious decline of the $\mathrm{NO}_{x}$ conversion.

The reaction temperature had a great impact on the performance of the SCR catalyst. Therefore, the $\mathrm{SO}_{2} / \mathrm{H}_{2} \mathrm{O}$ resistance of the $\mathrm{CeMo}_{0.5} \mathrm{Zr}_{2} \mathrm{O}_{x}$ catalyst was also conducted at $400{ }^{\circ} \mathrm{C}$. As shown in Figure S7A in the SI, the $\mathrm{NO}_{x}$ conversion still remained $100 \%$ after the introduction of $100 \mathrm{ppm}^{\circ} \mathrm{SO}_{2}$ at $400{ }^{\circ} \mathrm{C}$ for $48 \mathrm{~h}$, which was higher than that at $250^{\circ} \mathrm{C}$ in Figure $2 \mathrm{~A}$. The results indicated that the $\mathrm{SO}_{2}$ tolerance was improved as the reaction temperature increased from 250 to $400{ }^{\circ} \mathrm{C}$. As presented in Figure $\mathrm{S} 7 \mathrm{~B}$ in the $\mathrm{SI}, 5 \% \mathrm{H}_{2} \mathrm{O}$ alone has an insignificant effect on the SCR activity over the $\mathrm{CeMo}_{0.5} \mathrm{Zr}_{2} \mathrm{O}_{x}$ catalyst at $400{ }^{\circ} \mathrm{C}$ and $\mathrm{NO}_{x}$ conversion was almost $100 \%$. The results in Figure S7C in the SI demonstrated that when both $\mathrm{SO}_{2}$ and $\mathrm{H}_{2} \mathrm{O}$ were introduced to the reaction gas, the $\mathrm{NO}_{x}$ conversion exhibited a trend similar to that in Figure 2C.

In addition, as shown in Figure S8 in the SI, 500 ppm of $\mathrm{SO}_{2}$ was added to the reaction gas at $250{ }^{\circ} \mathrm{C}$ to evaluate the $\mathrm{SO}_{2}$ resistance of the $\mathrm{CeMo}_{0.5} \mathrm{Zr}_{2} \mathrm{O}_{x}$ catalyst. The results showed that the $\mathrm{NO}_{x}$ conversion was greatly declined from the initial $100 \%$ to $30 \%$, which was greatly different from the effect of 100 ppm on the $\mathrm{NO}_{x}$ conversion in Figure $2 \mathrm{~B}$, indicating that a higher concentration of $\mathrm{SO}_{2}$ would lead to a serious deactivation of the catalyst. However, in real applications, the concentration of $\mathrm{SO}_{2}$ from diesel engine exhaust depends on the sulfur content of the diesel fuel. In recent years, $\mathrm{SO}_{2}$ in diesel engine exhaust is only tens of parts per million, which is much lower than $500 \mathrm{ppm}$.

In order to further investigate the influence of $\mathrm{SO}_{2} / \mathrm{H}_{2} \mathrm{O}$ treatment on the $\mathrm{CeMo}_{0.5} \mathrm{Zr}_{2} \mathrm{O}_{x}$ catalyst, the $\mathrm{NH}_{3}$-SCR activity as a function of the reaction temperature of $\mathrm{CeMo}_{0.5} \mathrm{Zr}_{2} \mathrm{O}_{x}$ catalysts treated in $\mathrm{SO}_{2} / \mathrm{H}_{2} \mathrm{O}$ for $48 \mathrm{~h}$ in Figure 2 was retested, and the results are shown in Figure 3. Prior to the activity measurements of $\mathrm{CeMo}_{0.5} \mathrm{Zr}_{2} \mathrm{O}_{x}$ catalysts treated in $\mathrm{SO}_{2} / \mathrm{H}_{2} \mathrm{O}$

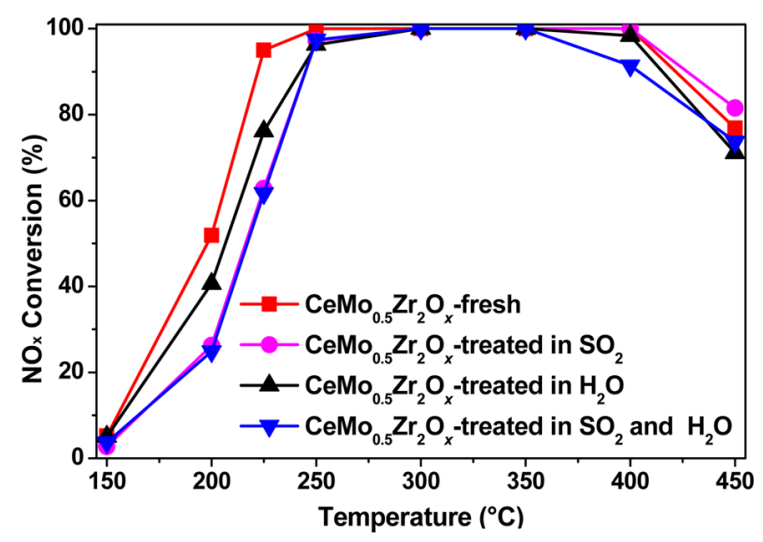

Figure 3. $\mathrm{NO}_{x}$ conversion in the $\mathrm{NH}_{3}$-SCR reaction as a function of the temperature over $\mathrm{CeMo}_{0.5} \mathrm{Zr}_{2} \mathrm{O}_{x}$ catalysts after treatment in $\mathrm{SO}_{2} /$ $\mathrm{H}_{2} \mathrm{O}$ for $48 \mathrm{~h}$. Reaction conditions: $[\mathrm{NO}]=\left[\mathrm{NH}_{3}\right]=500 \mathrm{ppm},\left[\mathrm{O}_{2}\right]=$ $5 \mathrm{vol} \%$, and GHSV $=50000 \mathrm{~h}^{-1}$.

for $48 \mathrm{~h}$, the catalysts were calcined at $400{ }^{\circ} \mathrm{C}$ for $1 \mathrm{~h}$ to eliminate the ammonium sulfate deposited on the surface of the catalysts. Compared to the fresh $\mathrm{CeMo}_{0.5} \mathrm{Zr}_{2} \mathrm{O}_{x}$ catalyst, the SCR activity of the catalysts treated in $\mathrm{SO}_{2} / \mathrm{H}_{2} \mathrm{O}$ showed a slight decrease between 150 and $250{ }^{\circ} \mathrm{C}$. However, the $\mathrm{NO}_{x}$ conversion was still kept at more than $90 \%$ in the temperature range from 250 to $400{ }^{\circ} \mathrm{C}$. Therefore, the $\mathrm{CeMo}_{0.5} \mathrm{Zr}_{2} \mathrm{O}_{x}$ catalyst exhibits strong resistance to $\mathrm{SO}_{2}$ and $\mathrm{H}_{2} \mathrm{O}$ poisoning, which can be used to remove $\mathrm{NO}_{x}$ from diesel engine exhaust containing a certain amount of $\mathrm{SO}_{2}$ and $\mathrm{H}_{2} \mathrm{O}$ vapor.

3.3. Effect of GHSV. The $\mathrm{NO}_{x}$ conversion over $\mathrm{CeMo}_{0.5} \mathrm{Zr}_{2} \mathrm{O}_{x}$ under different GHSVs is shown in Figure 4.

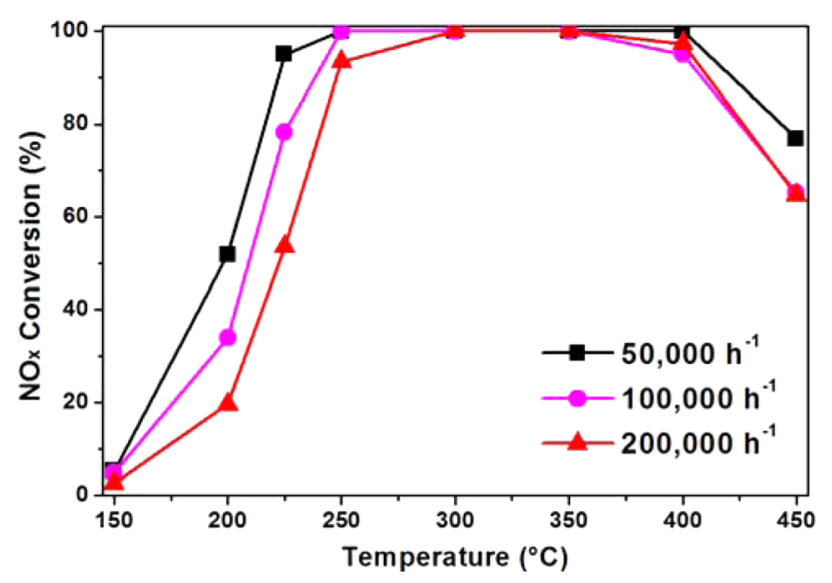

Figure 4. $\mathrm{NO}_{x}$ conversion in the $\mathrm{NH}_{3}$-SCR reaction as a function of the temperature over the $\mathrm{CeMo}_{0.5} \mathrm{Zr}_{2} \mathrm{O}_{x}$ catalyst under different GHSVs. Reaction conditions: $[\mathrm{NO}]=\left[\mathrm{NH}_{3}\right]=500 \mathrm{ppm}$ and $\left[\mathrm{O}_{2}\right]=5$ vol \%.

It can be seen that $\mathrm{NO}_{x}$ conversion below $250{ }^{\circ} \mathrm{C}$ decreased slightly when GHSV was increased from 50000 to $200000 \mathrm{~h}^{-1}$. However, even at the highest GHSV of $200000 \mathrm{~h}^{-1}, \mathrm{NO}_{x}$ conversion was still more than $90 \%$ in the temperature range from 250 to $400{ }^{\circ} \mathrm{C}$. The effect of GHSV on the $\mathrm{NO}_{x}$ conversion at high temperature was weaker than that at low temperature. These results indicated that the $\mathrm{CeMo}_{0.5} \mathrm{Zr}_{2} \mathrm{O}_{x}$ catalyst is highly effective for the removal of $\mathrm{NO}_{x}$ in a wide temperature range from 250 to $400{ }^{\circ} \mathrm{C}$ even when the reaction condition is harsh. 
3.4. Thermal Stability Test. In practical use, the $\mathrm{NH}_{3}$-SCR catalyst should also have good thermal stability in the long-term $\operatorname{deNO}_{x}$ process. At the same time, to meet tougher emission standards of diesel engine exhaust, the diesel particulate filter (DPF) has to be used. The diesel exhaust gas temperature can reach above $700{ }^{\circ} \mathrm{C}$ during the regeneration process of the DPF system. ${ }^{27}$ Therefore, the $\mathrm{CeMo}_{0.5} \mathrm{Zr}_{2} \mathrm{O}_{x}$ catalysts were calcined at different temperatures $\left(500,550,600,650,700\right.$, and $\left.750{ }^{\circ} \mathrm{C}\right)$ for $8 \mathrm{~h}$ to test the thermal stability, and the results are illustrated in Figure 5A. As the calcination temperature
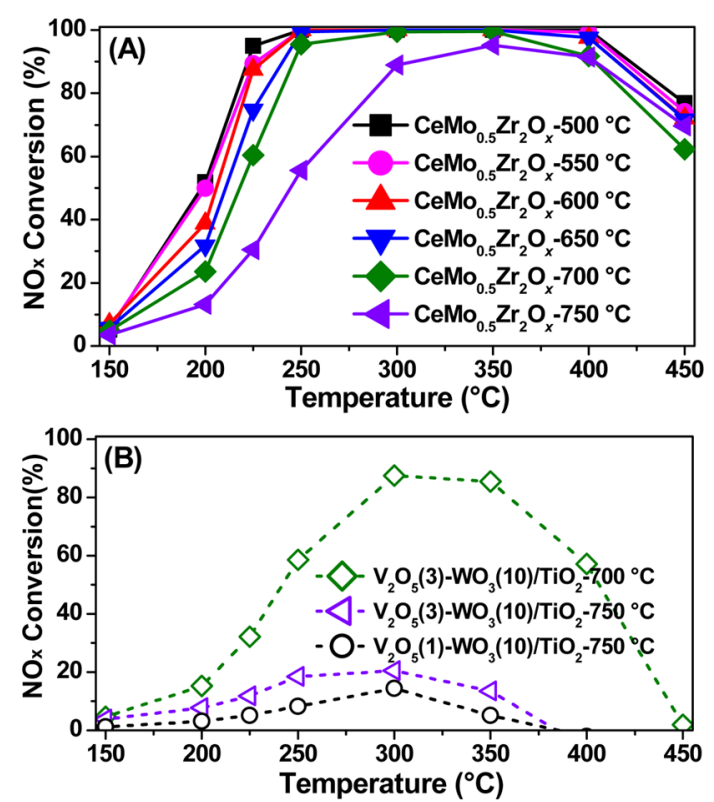

Figure 5. $\mathrm{NO}_{x}$ conversion in the $\mathrm{NH}_{3}$-SCR reaction as a function of the temperature over $\mathrm{CeMo}_{0.5} \mathrm{Zr}_{2} \mathrm{O}_{x}(\mathrm{~A})$ and $\mathrm{V}_{2} \mathrm{O}_{5}-\mathrm{WO}_{3} / \mathrm{TiO}_{2}$ (B) catalysts calcined at different temperatures for $8 \mathrm{~h}$. Reaction conditions: $[\mathrm{NO}]=\left[\mathrm{NH}_{3}\right]=500 \mathrm{ppm},\left[\mathrm{O}_{2}\right]=5 \mathrm{vol} \%$, and GHSV $=50000 \mathrm{~h}^{-1}$.

increased from 500 to $700{ }^{\circ} \mathrm{C}$, the $\mathrm{NO}_{x}$ conversion below $250{ }^{\circ} \mathrm{C}$ showed a slight and monotonic decrease, while the conversion above $250{ }^{\circ} \mathrm{C}$ was quite similar. Further increasing the calcination temperature to $750{ }^{\circ} \mathrm{C}$ resulted in an obvious decrease of the $\mathrm{NH}_{3}$-SCR activity at both low and high temperatures, which might be caused by the decrease of the surface area and sintering of the active component. For comparison purposes, the SCR activity of commercial $\mathrm{V}_{2} \mathrm{O}_{5}-$ $\mathrm{WO}_{3} / \mathrm{TiO}_{2}$ catalysts with various $\mathrm{V}_{2} \mathrm{O}_{5}$ contents calcined at 700 or $750{ }^{\circ} \mathrm{C}$ was also studied. As shown in Figure 5B, these catalysts show poor activity in the whole temperature range, which might be due to the decrease of the surface area, the anatase-to-rutile transition of $\mathrm{TiO}_{2}$, and the loss of vanadia. ${ }^{15}$ Compared to the commercial $\mathrm{V}_{2} \mathrm{O}_{5}-\mathrm{WO}_{3} / \mathrm{TiO}_{2}$ catalyst, the $\mathrm{CeMo}_{0.5} \mathrm{Zr}_{2} \mathrm{O}_{x}$ catalyst exhibits much better high-temperature stability.

Moreover, as shown in Figure S9 in the SI, the $\mathrm{CeMo}_{0.5} \mathrm{Zr}_{2} \mathrm{O}_{x}$ catalyst hydrothermally treated at $700{ }^{\circ} \mathrm{C}$ for $48 \mathrm{~h}$ still exhibited high $\mathrm{NH}_{3}$-SCR activity, over which more than $80 \% \mathrm{NO}_{x}$ conversion was obtained between 300 and $400{ }^{\circ} \mathrm{C}$. Further increasing the aging temperature to $760{ }^{\circ} \mathrm{C}$ would resulted in an obvious diminution of the SCR activity, indicating that $\mathrm{CeMo}_{0.5} \mathrm{Zr}_{2} \mathrm{O}_{x}$ could only be used below $700{ }^{\circ} \mathrm{C}$. The hydrothermal stability of the $\mathrm{CeMo}_{0.5} \mathrm{Zr}_{2} \mathrm{O}_{x}$ catalyst needs to be improved further in future studies.
3.5. $\mathrm{N}_{2}$ Physisorption and XRD Results. The specific surface area and $\mathrm{BJH}$ desorption pore volume of $\mathrm{MoO}_{3}$, $\mathrm{CeMo}_{a} \mathrm{Zr}_{2} \mathrm{O}_{x}$, and $\mathrm{CeMo}_{0.5} \mathrm{Zr}_{2} \mathrm{O}_{x}$ calcined at different temperatures are shown in Tables 1 and 2, respectively. As shown in

Table 1. BET Surface Area, Pore Volume, and $\mathrm{CeO}_{2}$ Crystallite Size of $\mathrm{MoO}_{3}$ and $\mathrm{CeMo}_{a} \mathrm{Zr}_{2} \mathrm{O}_{x}$

\begin{tabular}{lrcc}
\multicolumn{1}{c}{ catalyst } & $\begin{array}{c}\mathrm{S}_{\mathrm{BET}}{ }^{a} \\
\left(\mathrm{~m}^{2} / \mathrm{g}\right)\end{array}$ & $\begin{array}{c}\text { pore volume } \\
\left(\mathrm{cm}^{3} / \mathrm{g}\right)\end{array}$ & $\begin{array}{c}\mathrm{CeO}_{2} \text { crystallite size }^{c} \\
(\mathrm{~nm})\end{array}$ \\
$\mathrm{MoO}_{3}$ & 1.4 & 0.006 & \\
$\mathrm{CeZr}_{2} \mathrm{O}_{x}$ & 107.3 & 0.097 & 11.8 \\
$\mathrm{CeMo}_{0.1} \mathrm{Zr}_{2} \mathrm{O}_{x}$ & 109.1 & 0.079 & 11.4 \\
$\mathrm{CeMo}_{0.5} \mathrm{Zr}_{2} \mathrm{O}_{x}$ & 82.6 & 0.037 & 11.2 \\
$\mathrm{CeMo}_{1.0} \mathrm{Zr}_{2} \mathrm{O}_{x}$ & 61.0 & 0.028 & 9.6 \\
$\mathrm{CeMo}_{1.5} \mathrm{Zr}_{2} \mathrm{O}_{x}$ & 51.5 & 0.027 & 9.5
\end{tabular}

${ }^{a} \mathrm{BET}$ surface area. ${ }^{b} \mathrm{BJH}$ desorption pore volume. ${ }^{c} \mathrm{CeO}_{2}$ crystallite size calculated by the Scherrer equation from the $\mathrm{XRD}$ results.

Table 2. BET Surface Area, Pore Volume, and $\mathrm{CeO}_{2}$ Crystallite Size of $\mathrm{CeMo}_{0.5} \mathrm{Zr}_{2} \mathrm{O}_{x}$ Calcined at Different Temperatures for $8 \mathrm{~h}$

\begin{tabular}{|c|c|c|c|}
\hline catalyst & $\begin{array}{c}S_{\mathrm{BET}} \\
\left(\mathrm{m}^{2} / \mathrm{g}\right)\end{array}$ & $\begin{array}{l}\text { pore volume } \\
\left(\mathrm{cm}^{3} / \mathrm{g}\right)\end{array}$ & $\underset{(\mathrm{nm})}{\mathrm{CeO}_{2} \text { crystallite size }}$ \\
\hline $\begin{array}{l}\mathrm{CeMo}_{0.5} \mathrm{Zr}_{2} \mathrm{O}_{x^{-}} \\
500{ }^{\circ} \mathrm{C}\end{array}$ & 77.8 & 0.038 & 12.1 \\
\hline $\begin{array}{l}\mathrm{CeMo}_{0.5} \mathrm{Zr}_{2} \mathrm{O}_{x^{-}} \\
550{ }^{\circ} \mathrm{C}\end{array}$ & 75.8 & 0.040 & 12.1 \\
\hline $\begin{array}{l}\mathrm{CeMo}_{0.5} \mathrm{Zr}_{2} \mathrm{O}_{x^{-}} \\
600{ }^{\circ} \mathrm{C}\end{array}$ & 71.3 & 0.058 & 14.8 \\
\hline $\begin{array}{l}\mathrm{CeMo}_{0.5} \mathrm{Zr}_{2} \mathrm{O}_{x^{-}} \\
650{ }^{\circ} \mathrm{C}\end{array}$ & 47.7 & 0.070 & 15.9 \\
\hline $\begin{array}{l}\mathrm{CeMo}_{0.5} \mathrm{Zr}_{2} \mathrm{O}_{x^{-}} \\
\quad 700{ }^{\circ} \mathrm{C}\end{array}$ & 33.0 & 0.070 & 21.2 \\
\hline $\begin{array}{l}\mathrm{CeMo}_{0.5} \mathrm{Zr}_{2} \mathrm{O}_{x^{-}} \\
750{ }^{\circ} \mathrm{C}\end{array}$ & 21.1 & 0.063 & 22.4 \\
\hline
\end{tabular}

Table 1, the addition of a small amount of Mo (Mo:Ce = 0.1:1) to $\mathrm{CeZr}_{2} \mathrm{O}_{x}$ showed a negligible effect on the surface area. However, when the molar ratio of Mo:Ce was more than $0.5: 1$, the surface area of the catalysts decreased obviously as the Mo loading increased because of the quite small surface area of $\mathrm{MoO}_{3}$. It was also reported that the addition of Mo could reduce the surface area of $\mathrm{MoO}_{3}-\mathrm{CeO}_{2}$ catalysts, which were prepared by coprecipitation using urea as the precipitant. $^{28}$ Meanwhile, the doping of Mo into $\mathrm{CeZr}_{2} \mathrm{O}_{x}$ decreased the pore volume.

Table 2 shows the surface area and pore volume of $\mathrm{CeMo}_{0.5} \mathrm{Zr}_{2} \mathrm{O}_{x}$ calcined at different temperatures. It could be seen that increasing the calcination temperature from 500 to $750{ }^{\circ} \mathrm{C}$ resulted in a decrease of the surface area from 77.8 to $21.1 \mathrm{~m}^{2} / \mathrm{g}$, while the pore volume increased gradually. The decrease of the surface area and the sintering of the active component at high calcination temperatures might be responsible for the decrease of the $\mathrm{NO}_{x}$ conversion at low temperatures. $^{29}$

The XRD results of the catalysts with different Mo loadings are summarized in Figure 6A. The reflections provided typical diffraction patterns for the $\mathrm{CeO}_{2}$ cubic phase (JCPDS 34-0394) and the $\mathrm{ZrO}_{2}$ tetragonal phase (JCPDS 50-1089). No diffraction peaks attributed to Mo species were detected in the XRD patterns, implying that Mo species were finely dispersed on the surface of the catalysts or existed as amorphous species. Furthermore, as shown in Table 1, the 

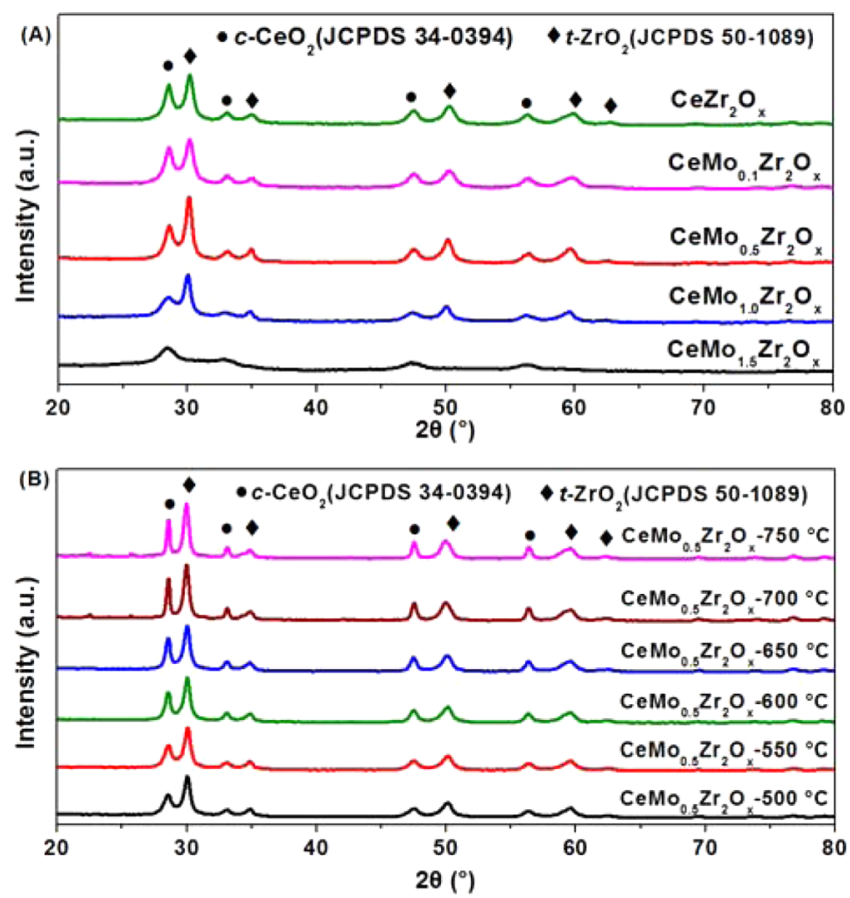

Figure 6. Powder $\mathrm{XRD}$ of $\mathrm{CeMo}_{a} \mathrm{Zr}_{2} \mathrm{O}_{x}$ catalysts with different $\mathrm{Mo}$ loadings (A) and $\mathrm{CeMo}_{0.5} \mathrm{Zr}_{2} \mathrm{O}_{x}$ catalysts calcined at different temperatures for $8 \mathrm{~h}(\mathrm{~B})$.

average crystallite size of $\mathrm{CeO}_{2}$ calculated by the Scherrer equation decreased slightly as the Mo content increased. As presented in Figure 6B, the XRD patterns of $\mathrm{CeMo}_{0.5} \mathrm{Zr}_{2} \mathrm{O}_{x}$ samples calcined at various temperatures from 500 to $750{ }^{\circ} \mathrm{C}$ for $8 \mathrm{~h}$ showed typical diffraction peaks for the cubic $\mathrm{CeO}_{2}$ and tetragonal $\mathrm{ZrO}_{2}$ phases, and no diffraction peaks for Mo species were detected. With increasing calcination temperature, the intensities of all of the diffraction peaks increased slightly and the $\mathrm{CeO}_{2}$ average crystallite size increased from 12.1 to $22.4 \mathrm{~nm}$ (Table 2). However, after high-temperature calcination, the positions of the diffraction peaks stayed the same, indicating that changes of the crystallite phases of $\mathrm{CeO}_{2}$ and $\mathrm{ZrO}_{2}$ did not occur in this process.

3.6. Raman Spectra. Visible Raman spectra were also applied to characterize the $\mathrm{CeMo}_{a} \mathrm{Zr}_{2} \mathrm{O}_{x}$ catalysts, and the results are presented in Figure 7. $\mathrm{CeZr}_{2} \mathrm{O}_{x}$ showed an obvious band at $463 \mathrm{~cm}^{-1}$ and three weak peaks at about 630,315 , and

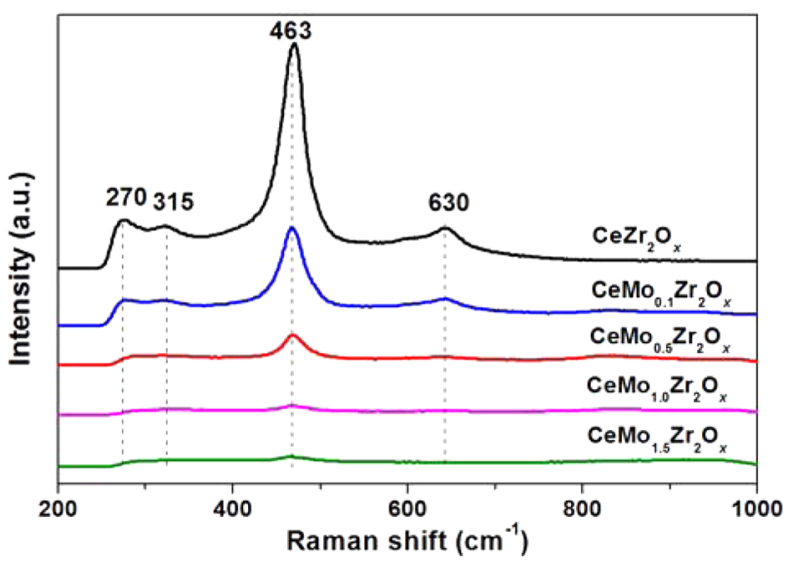

Figure 7. Visible Raman spectra of the $\mathrm{CeMo}_{a} \mathrm{Zr}_{2} \mathrm{O}_{x}$ catalysts.
$270 \mathrm{~cm}^{-1}$. The band at $463 \mathrm{~cm}^{-1}$ was due to the Raman-active $\mathrm{F}_{2 \mathrm{~g}}$ mode of the $\mathrm{CeO}_{2}$ fluorite structure. ${ }^{30}$ The band at 630 $\mathrm{cm}^{-1}$ could be a consequence of the lattice contraction brought about by $\mathrm{Zr}$ ion insertion. ${ }^{9}$ The bands at 315 and $270 \mathrm{~cm}^{-1}$ could be assigned to the $\mathrm{Zr}$ phase $\left(t-\mathrm{ZrO}_{2}\right) \cdot{ }^{31-33}$ With an increase of the Mo content, the Raman spectral intensity of $\mathrm{CeO}_{2}$ decreased significantly, which proved that the introduction of $\mathrm{Mo}$ inhibited growth of the $\mathrm{CeO}_{2}$ particle size. ${ }^{25}$ These analytical results are in good accordance with the conclusion drawn from XRD results. In combination with the XRD and Raman results, it could be concluded that Mo species were mainly present in a highly dispersed state and the addition of Mo resulted in a decrease of the $\mathrm{CeO}_{2}$ crystallite size. However, the $\mathrm{CeO}_{2}$ crystallite size was not the only factor leading to the discrepancy of the catalytic activity between different catalysts.

3.7. $\mathrm{H}_{2}-\mathrm{TPR} . \mathrm{H}_{2}$-TPR experiments were conducted to investigate the redox ability of the catalysts, and the results are shown in Figure 8. For the $\mathrm{CeZr}_{2} \mathrm{O}_{x}$ catalyst, the reduction

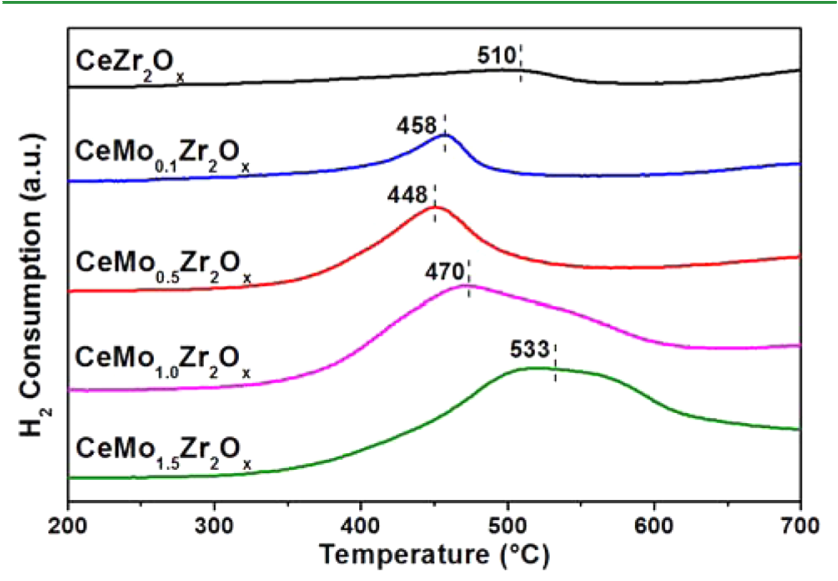

Figure 8. $\mathrm{H}_{2}-\mathrm{TPR}$ profiles of the $\mathrm{CeMo}_{a} \mathrm{Zr}_{2} \mathrm{O}_{x}$ catalysts.

peak at about $510{ }^{\circ} \mathrm{C}$ was attributed to the reduction of surface $\mathrm{Ce}^{4+}$ to $\mathrm{Ce}^{3+} \cdot{ }^{25,34}$ After the introduction of $\mathrm{Mo}$ to $\mathrm{CeZr}_{2} \mathrm{O}_{x}$, the reduction peak of surface $\mathrm{Ce}^{4+}$ moved to lower temperatures, which indicated that the mobility of surface $\mathrm{O}$ was greatly improved because of the strong synergetic effect among $\mathrm{Zr}, \mathrm{Ce}$, and Mo species. It is believed that the synergetic effect gave rise to severe structural distortion and abundant $O$ defects. ${ }^{16,35}$ The $\mathrm{O}$ defects facilitated $\mathrm{O}$ diffusion from the subsurface layers and might progressively proceed deeper into the bulk. ${ }^{36,37}$ All of the above features were beneficial for the SCR activity. In addition, it was also reported that the mobility of surface $\mathrm{O}$ on the CeMoAlO $x$ catalyst was enhanced by Mo addition. ${ }^{38}$ $\mathrm{CeMo}_{0.5} \mathrm{Zr}_{2} \mathrm{O}_{x}$ exhibited the lowest reduction temperature at $448{ }^{\circ} \mathrm{C}$, which was in harmony with its highest SCR activity. However, upon a further increase of the Mo/Ce molar ratios from 0.5 to 1.5 , the reduction peaks attributed to the overlap of $\mathrm{Ce}$ and Mo species shifted to higher temperatures, which might be caused by the coverage of Mo species. These results indicate that the stronger oxidation reduction ability of $\mathrm{CeMo}_{0.5} \mathrm{Zr}_{2} \mathrm{O}_{x}$ benefits the excellent SCR reaction performance.

3.8. In Situ DRIFTS Studies. 3.8.1. $\mathrm{NH}_{3}$ Adsorption. In situ DRIFTS spectra of $\mathrm{NH}_{3}$ adsorption at $200{ }^{\circ} \mathrm{C}$ were measured to examine the change of acidity on the catalysts after $\mathrm{Mo}$ addition, and the results are shown in Figure 9A. After exposure to $\mathrm{NH}_{3}$, the catalysts were covered by several kinds of $\mathrm{NH}_{3}$ species. The bands at $1668 \mathrm{~cm}^{-1}$ and 1425,1440 , and 1414 $\mathrm{cm}^{-1}$ were assigned to symmetric and asymmetric bending 

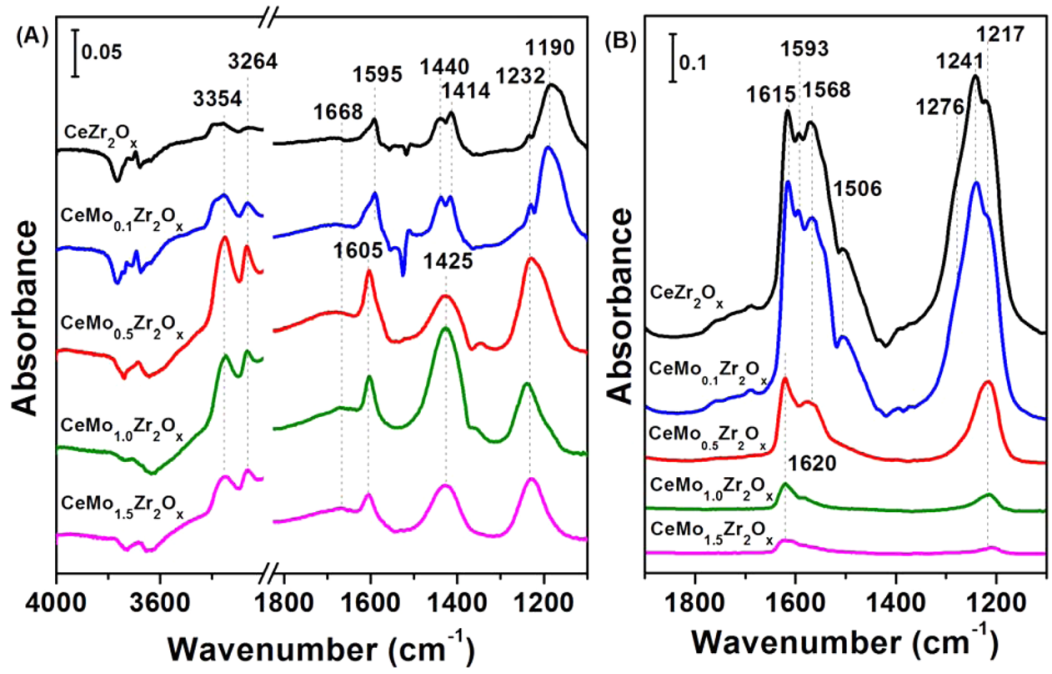

Figure 9. In situ DRIFTS of $\mathrm{NH}_{3}$ adsorption (A) and $\mathrm{NO}+\mathrm{O}_{2}$ adsorption (B) at $200{ }^{\circ} \mathrm{C}$ on the $\mathrm{CeMo}_{a} \mathrm{Zr}_{2} \mathrm{O}_{x}$ series of catalysts.
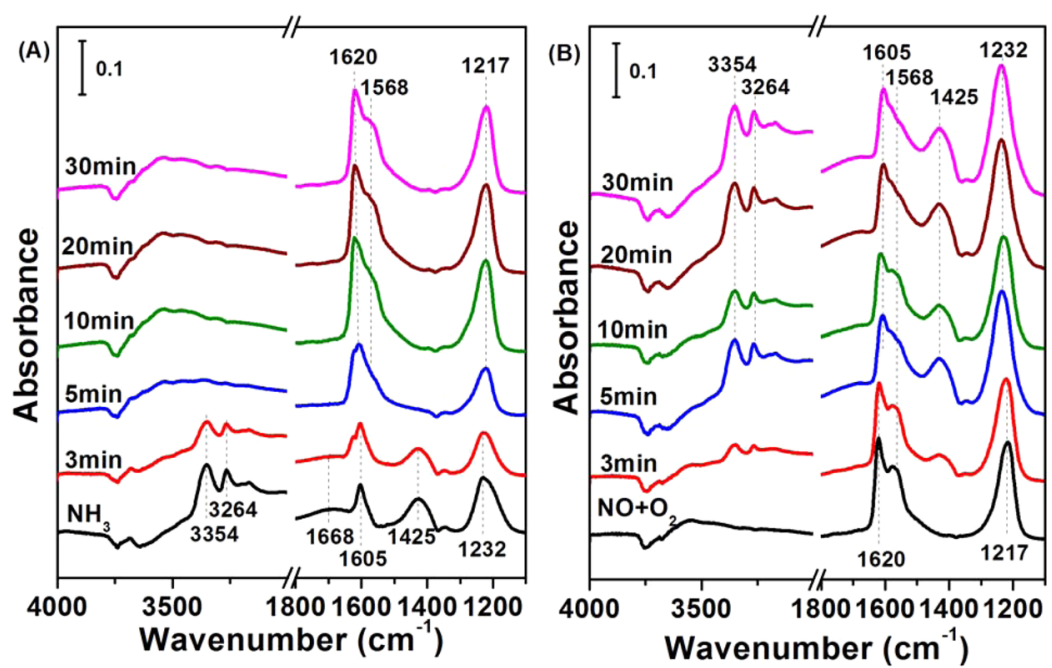

Figure 10. In situ DRIFTS of $\mathrm{NO}+\mathrm{O}_{2}$ reacted with preadsorbed $\mathrm{NH}_{3}$ species (A) and $\mathrm{NH}_{3}$ reacted with preadsorbed $\mathrm{NO}_{x}$ species $(\mathrm{B})$ at $200{ }^{\circ} \mathrm{C}$ on the $\mathrm{CeMo}_{0.5} \mathrm{Zr}_{2} \mathrm{O}_{x}$ catalyst.

vibrations, respectively, of $\mathrm{NH}_{4}^{+}$species on Brønsted acid sites. ${ }^{5,22,39-41}$ The bands at 1605 and $1595 \mathrm{~cm}^{-1}$ and at 1232 and $1190 \mathrm{~cm}^{-1}$ were attributed to asymmetric and symmetric bending vibrations, respectively, of the $\mathrm{N}-\mathrm{H}$ bonds in coordinated $\mathrm{NH}_{3}$ linked to Lewis acid sites, respectively. ${ }^{42,43}$ The bands at 3354 and $3264 \mathrm{~cm}^{-1}$ ascribed to $\mathrm{N}-\mathrm{H}$ stretching modes of coordinated $\mathrm{NH}_{3}$ were also observed. ${ }^{23}$ Some negative bands around $3700 \mathrm{~cm}^{-1}$ were also found that could be assigned to hydroxyl consumption due to interaction between the hydroxyl groups and $\mathrm{NH}_{3}$ to form $\mathrm{NH}_{4}{ }^{+} \cdot$, 35

Compared to $\mathrm{CeZr}_{2} \mathrm{O}_{x}$, the addition of Mo enhanced the band intensities of adsorbed $\mathrm{NH}_{4}^{+}$greatly. This meant that the introduction of Mo resulted in more Brønsted acid sites on the catalyst surface, and similar results were also found on $\mathrm{CeO}_{2}-$ $\mathrm{MoO}_{3}$ catalysts in the published literature. ${ }^{25,28}$ For coordinated $\mathrm{NH}_{3}$ bound to Lewis acid sites, the band intensity first had an obvious increase and then showed a decrease when the molar ratio of Mo:Ce was higher than 0.5:1. In addition, the $\mathrm{NH}_{3}$ TPD results indicated that the total amount of $\mathrm{NH}_{3}$ adsorbed on $\mathrm{CeMo}_{0.5} \mathrm{Zr}_{2} \mathrm{O}_{x}$ was higher than that on the $\mathrm{CeZr}_{2} \mathrm{O}_{x}$ catalyst; see Figure S10A in the SI. The band intensity due to Lewis acid sites over $\mathrm{CeMo}_{0.5} \mathrm{Zr}_{2} \mathrm{O}_{x}$ was the highest among the series of catalysts, which was in good accordance with the results of the SCR activity. Although the intensity of adsorbed $\mathrm{NH}_{4}^{+}$over $\mathrm{CeMo}_{1.0} \mathrm{Zr}_{2} \mathrm{O}_{x}$ was stronger than that over $\mathrm{CeMo}_{0.5} \mathrm{Zr}_{2} \mathrm{O}_{x}$, $\mathrm{CeMo}_{0.5} \mathrm{Zr}_{2} \mathrm{O}_{x}$ exhibited higher band intensity attributed to coordinated $\mathrm{NH}_{3}$ adsorption. It can be concluded that the Lewis acid sites over the $\mathrm{CeMo}_{0.5} \mathrm{Zr}_{2} \mathrm{O}_{x}$ catalyst are responsible for its highest SCR activity. Peng et al. investigated the structure activity relationship of the $\mathrm{MoO}_{3}-\mathrm{CeO}_{2}$ catalyst for $\mathrm{NH}_{3}$-SCR of $\mathrm{NO}_{x}$ and found that the Lewis acid sites could be involved in the reaction even more rapidly than the Brønsted acid sites. $^{28}$

3.8.2. $\mathrm{NO}+\mathrm{O}_{2}$ Adsorption. Figure 9B presents the in situ DRIFTS results of $\mathrm{NO}_{x}$ adsorption at $200{ }^{\circ} \mathrm{C}$. After $\mathrm{NO}+\mathrm{O}_{2}$ adsorption and $\mathrm{N}_{2}$ purge, several distinct bands attributed to monodentate nitrate $\left(1506\right.$ and $\left.1276 \mathrm{~cm}^{-1}\right)$, bidentate nitrate (1593 and $\left.1568 \mathrm{~cm}^{-1}\right)$, and bridging nitrate $(1615,1620,1241$, and $\left.1217 \mathrm{~cm}^{-1}\right)$ appeared. ${ }^{39,44-46}$ With increasing Mo addition content, the bands due to adsorbed nitrate species showed an obvious decrease in intensity, and only bridging nitrate species were observed on the $\mathrm{CeMo}_{1.5} \mathrm{Zr}_{2} \mathrm{O}_{x}$ catalyst. It is concluded that the addition of Mo significantly limits the adsorption of nitrate species, which could also be confirmed by the results 
drawn from NO-TPD in Figure S10B in the SI. It is believed that the introduction of $\mathrm{MoO}_{3}$ resulted in the formation of more acid sites accompanied by the reduction of basic sites where nitrate adsorbed. ${ }^{22}$ The inhibitory effect of Mo on the adsorption of nitrate species has also been reported by other researchers on the $\mathrm{MoO}_{3}-\mathrm{CeO}_{2} / \mathrm{TiO}_{2}{ }^{22}$ and $\mathrm{CeMo}_{0.5} \mathrm{AlO}_{x}{ }^{38}$ catalysts for the $\mathrm{NH}_{3}$-SCR process.

3.8.3. Reaction between $\mathrm{NO}+\mathrm{O}_{2}$ and Adsorbed $\mathrm{NH}_{3}$ Species. To investigate the reactivity of adsorbed $\mathrm{NH}_{3}$ species in the SCR reaction on the $\mathrm{CeMo}_{0.5} \mathrm{Zr}_{2} \mathrm{O}_{x}$ catalyst, in situ DRIFTS of the reaction between preadsorbed $\mathrm{NH}_{3}$ and $\mathrm{NO}+$ $\mathrm{O}_{2}$ at $200{ }^{\circ} \mathrm{C}$ was recorded as a function of time (Figure 10A). After the introduction of $\mathrm{NO}+\mathrm{O}_{2}$, the bands ascribed to ionic $\mathrm{NH}_{4}^{+}\left(1668\right.$ and $\left.1425 \mathrm{~cm}^{-1}\right)$ and coordinated $\mathrm{NH}_{3}$ (3354, 3264,1605 , and $1232 \mathrm{~cm}^{-1}$ ) showed an apparent decrease in intensity, and all of the bands were replaced by nitrate species after $5 \mathrm{~min}$. This indicates that both coordinated $\mathrm{NH}_{3}$ and ionic $\mathrm{NH}_{4}^{+}$on the $\mathrm{CeMo}_{0.5} \mathrm{Zr}_{2} \mathrm{O}_{x}$ catalyst could react as reducing agents to reduce $\mathrm{NO}_{x}$. Although coordinated $\mathrm{NH}_{3}$ over the $\mathrm{CeMo}_{0.5} \mathrm{Zr}_{2} \mathrm{O}_{x}$ catalyst was responsible for its highest SCR activity, ionic $\mathrm{NH}_{4}{ }^{+}$could also be involved in the SCR reaction. It could be concluded that the addition of Mo to $\mathrm{CeZr}_{2} \mathrm{O}_{x}$ resulted in more coordinated $\mathrm{NH}_{3}$ and ionic $\mathrm{NH}_{4}^{+}$, both of which could participate in the $\mathrm{NH}_{3}$-SCR reaction.

3.8.4. Reaction between $\mathrm{NH}_{3}$ and Adsorbed $\mathrm{NO}_{x}$ Species. The reactivity of absorbed $\mathrm{NO}_{x}$ species in the SCR reaction on the $\mathrm{CeMo}_{0.5} \mathrm{Zr}_{2} \mathrm{O}_{x}$ catalyst was also investigated by the in situ DRIFTS of the reaction between preadsorbed $\mathrm{NO}_{x}$ and $\mathrm{NH}_{3}$ at $200{ }^{\circ} \mathrm{C}$, and the results are shown in Figure 10B. After exposure to $\mathrm{NO}+\mathrm{O}_{2}$, the catalyst was mainly covered by bidentate nitrate $\left(1568 \mathrm{~cm}^{-1}\right)$ and bridging nitrate (1620 and 1217 $\mathrm{cm}^{-1}$ ). When $\mathrm{NH}_{3}$ was introduced, the bridging nitrate was greatly decreased and disappeared in $5 \mathrm{~min}$, while the bidentate nitrate did not show an obvious decrease. At the same time, the bands attributed to ionic $\mathrm{NH}_{4}^{+}\left(1668\right.$ and $\left.1425 \mathrm{~cm}^{-1}\right)$ and coordinated $\mathrm{NH}_{3}\left(3354,3264,1605\right.$, and $\left.1232 \mathrm{~cm}^{-1}\right)$ were observed after $5 \mathrm{~min}$. The results indicate that bridging nitrate rather than bidentate nitrate can react with $\mathrm{NH}_{3}$. Although the addition of Mo inhibited the adsorption of nitrate species on the surface, the reaction between adsorbed nitrate species and $\mathrm{NH}_{3}$ still played a significant role in the reduction of $\mathrm{NO}_{x}$. Judging from Figure 9B, the amount of nitrate species on $\mathrm{CeMo}_{0.1} \mathrm{Zr}_{2} \mathrm{O}_{x}$ was higher than that on other Mo-containing catalysts, indicating that $\mathrm{CeMo}_{0.1} \mathrm{Zr}_{2} \mathrm{O}_{x}$ should be an excellent catalyst for the SCR reaction. However, the lack of enough $\mathrm{NH}_{3}$ species on the surface of $\mathrm{CeMo}_{0.1} \mathrm{Zr}_{2} \mathrm{O}_{x}$ (Figure 9A) lowered SCR conversion, as seen in Figure 1. The adsorption amounts of coordinated $\mathrm{NH}_{3}$ and nitrate species on $\mathrm{CeMo}_{0.5} \mathrm{Zr}_{2} \mathrm{O}_{x}$ were both higher than that on $\mathrm{CeMo}_{1.0} \mathrm{Zr}_{2} \mathrm{O}_{x}$ or $\mathrm{CeMo}_{1.5} \mathrm{Zr}_{2} \mathrm{O}_{x}$. It is believed that the adsorption of $\mathrm{NH}_{3}$ and $\mathrm{NO}_{x}$ was considered to be essential in the $\mathrm{NH}_{3}$-SCR reaction at low temperatures. Liu et al. investigated the promoting effect of $\mathrm{MoO}_{3}$ on the $\mathrm{NH}_{3}$-SCR activity over the $\mathrm{CeO}_{2} / \mathrm{TiO}_{2}$ catalyst and believed that the unsaturated Mo resulted in more acid sites, which was favorable for the adsorption of $\mathrm{NH}_{3}$, thus improving the low-temperature activity. ${ }^{22}$ Nitro and nitrate groups were beneficial to promote the SCR process at low temperatures over an F-doped $\mathrm{CeO}_{2}-\mathrm{TiO}_{2}$ catalyst. ${ }^{47}$ In addition, the results in Figure 10 show that both adsorbed $\mathrm{NH}_{3}$ species (coordinated $\mathrm{NH}_{3}$, ionic $\mathrm{NH}_{4}^{+}$) and adsorbed bridging nitrate species were active in the $\mathrm{NH}_{3}$-SCR action. Therefore, it was reasonable to conclude that the high adsorption amounts of $\mathrm{NH}_{3}$ and nitrate species were favorable for the high activity of the $\mathrm{CeMo}_{0.5} \mathrm{Zr}_{2} \mathrm{O}_{x}$ catalyst.

\section{CONCLUSIONS}

A novel Mo-promoted $\mathrm{Ce}-\mathrm{Zr}$ catalyst prepared by a homogeneous precipitation method was used for $\mathrm{NH}_{3}$-SCR of $\mathrm{NO}_{x}$. The $\mathrm{CeMo}_{0.5} \mathrm{Zr}_{2} \mathrm{O}_{x}$ catalyst with a Mo:Ce molar ratio of 0.5:1 showed high SCR activity, $\mathrm{SO}_{2} / \mathrm{H}_{2} \mathrm{O}$ durability, and thermal stability under test conditions. Characterization results indicated that $\mathrm{Mo}$ addition inhibited growth of the $\mathrm{CeO}_{2}$ particle size, improved the redox ability, and increased the amount of surface acidity, especially the Lewis acidity. Coordinated $\mathrm{NH}_{3}$ and ionic $\mathrm{NH}_{4}^{+}$species together with bridging nitrate were active over the $\mathrm{CeMo}_{0.5} \mathrm{Zr}_{2} \mathrm{O}_{x}$ catalyst during the $\mathrm{NH}_{3}-\mathrm{SCR}$ reaction. All of the features above are responsible for the excellent $\mathrm{NH}_{3}-\mathrm{SCR}$ performance.

\section{ASSOCIATED CONTENT}

\section{Supporting Information}

$\mathrm{pH}$ value variation during the preparation, distribution of $\mathrm{Zr}$, $\mathrm{Ce}$, and $\mathrm{Mo}$ on $\mathrm{CeMo}_{0.5} \mathrm{Zr}_{2} \mathrm{O}_{x}$ catalyst, designed and actual bulk molar ratios, $\mathrm{NO}_{x}$ conversion and $\mathrm{N}_{2}$ selectivity in $\mathrm{NH}_{3}$ $\mathrm{SCR}$ reaction over $\mathrm{V}_{2} \mathrm{O}_{5}-\mathrm{WO}_{3} / \mathrm{TiO}_{2}$, effect of $\mathrm{SO}_{2}, \mathrm{H}_{2} \mathrm{O}, \mathrm{SO}_{2}+$ $\mathrm{H}_{2} \mathrm{O}$ at $400{ }^{\circ} \mathrm{C}$, and $500 \mathrm{ppm} \mathrm{SO} \mathrm{S}_{2}$ at $250{ }^{\circ} \mathrm{C}$ on the SCR activity, and $\mathrm{NH}_{3}$-TPD and NO-TPD results. The Supporting Information is available free of charge on the ACS Publications website at DOI: 10.1021/acsami.5b00636.

\section{AUTHOR INFORMATION}

\section{Corresponding Authors}

*E-mail: fudongliu@lbl.gov or lfd1982@gmail.com. Tel: +86 1062849123 . Fax: +861062849123.

*E-mail: honghe@rcees.ac.cn. Tel: +86 10 62849123. Fax: +86 1062849123.

\section{Present Address}

${ }^{\dagger}$ F.L.: Materials Sciences Division, Lawrence Berkeley National Laboratory, 1 Cyclotron Road, Berkeley, CA 94720.

\section{Author Contributions}

The manuscript was written through contributions of all authors. All authors have given approval to the final version of the manuscript.

\section{Notes}

The authors declare no competing financial interest.

\section{ACKNOWLEDGMENTS}

This work was supported by the National Natural Science Foundation of China (Grant 51221892) and the Ministry of Science and Technology China (Grant 2013AA065301).

\section{REFERENCES}

(1) Pavulescu, V. I.; Grange, P.; Delmon, B. Catalytic Removal of NO. Catal. Today 1998, 46, 233-316.

(2) Koebel, M.; Elsener, M.; Kleemann, M. Urea-SCR: a Promising Technique to Reduce $\mathrm{NO}_{\mathrm{x}}$ Emissions from Automotive Diesel Engines. Catal. Today 2000, 59, 335-345.

(3) Brandenberger, S.; Kröcher, O.; Tissler, A.; Althoff, R. The State of the Art in Selective Catalytic Reduction of $\mathrm{NO}_{x}$ by Ammonia Using Metal-Exchanged Zeolite Catalysts. Catal. Rev. 2008, 50, 492-531.

(4) Grossale, A.; Nova, I.; Tronconi, E. Ammonia Blocking of the "Fast SCR" Reactivity over a Commercial Fe-zeolite Catalyst for Diesel Exhaust Aftertreatment. J. Catal. 2009, 265, 141-147.

(5) Liu, F. D.; He, H.; Ding, Y.; Zhang, C. B. Effect of Manganese Substitution on the Structure and Activity of Iron Titanate Catalyst for 
the Selective Catalytic Reduction of $\mathrm{NO}$ with $\mathrm{NH}_{3}$. Appl. Catal., B 2009, 93, 194-204.

(6) Paier, J.; Penschke, C.; Sauer, J. Oxygen Defects and Surface Chemistry of Ceria: Quantum Chemical Studies Compared to Experiment. Chem. Rev. 2013, 113, 3949-3985.

(7) Ma, Z. R.; Weng, D.; Wu, X. D.; Si, Z. C. Effects of $\mathrm{WO}_{x}$ Modification on the Activity, Adsorption and Redox Properties of $\mathrm{CeO}_{2}$ Catalyst for $\mathrm{NO}_{x}$ Reduction with Ammonia. J. Environ. Sci. (Beijing, China) 2012, 24, 1305-1316.

(8) Zhang, D.; Du, X.; Shi, L.; Gao, R. Shape-Controlled Synthesis and Catalytic Application of Ceria Nanomaterials. Dalton Trans. 2012, 41, 14455-75.

(9) Shang, D. H.; Cai, W.; Zhao, W.; Bu, Y. F.; Zhong, Q. Catalytic Oxidation of $\mathrm{NO}$ to $\mathrm{NO}_{2}$ over $\mathrm{Co}-\mathrm{Ce}-\mathrm{Zr}$ Solid Solutions: Enhanced Performance of Ce-Zr Solid Solution by Co. Catal. Lett. 2014, 144, $538-544$.

(10) Hori, C. E.; Permana, H.; Ng, K. Y. S.; Brenner, A.; More, K.; Rahmoeller, K. M.; Belton, D. Thermal Stability of Oxygen Storage Properties in a Mixed $\mathrm{CeO}_{2}-\mathrm{ZrO}_{2}$ System. Appl. Catal., B 1998, 16, $105-117$.

(11) Terribile, D.; Trovarelli, A.; Llorca, J.; de Leitenburg, C.; Dolcetti, G. The Preparation of High Surface Area $\mathrm{CeO}_{2}-\mathrm{ZrO}_{2}$ Mixed Oxides by a Surfactant-Assisted Approach. Catal. Today 1998, 43, 7988

(12) Si, Z.; Weng, D.; Wu, X.; Yang, J.; Wang, B. Modifications of $\mathrm{CeO}_{2}-\mathrm{ZrO}_{2}$ Solid Solutions by Nickel and Sulfate as Catalysts for NO Reduction with Ammonia in Excess $\mathrm{O}_{2}$. Catal. Commun. 2010, 11, 1045-1048.

(13) Maitarad, P.; Han, J.; Zhang, D.; Shi, L.; Namuangruk, S.; Rungrotmongkol, T. Structure-Activity Relationships of $\mathrm{NiO}$ on $\mathrm{CeO}_{2}$ Nanorods for the Selective Catalytic Reduction of NO with $\mathrm{NH}_{3}$ : Experimental and DFT Studies. J. Phys. Chem. C 2014, 118, 9612-9620.

(14) Shen, B.; Wang, Y.; Wang, F.; Liu, T. The Effect of Ce-Zr on $\mathrm{NH}_{3}$-SCR Activity over $\mathrm{MnO}_{x}(0.6) / \mathrm{Ce}_{0.5} \mathrm{Zr}_{0.5} \mathrm{O}_{2}$ at Low Temperature. Chem. Eng. J. 2014, 236, 171-180.

(15) Li, Y.; Cheng, H.; Li, D.; Qin, Y.; Xie, Y.; Wang, S. $\mathrm{WO}_{3} /$ $\mathrm{CeO}_{2}-\mathrm{ZrO}_{2}$, a Promising Catalyst for Selective Catalytic Reduction (SCR) of $\mathrm{NO}_{x}$ with $\mathrm{NH}_{3}$ in Diesel Exhaust. Chem. Commun. 2008, $1470-1472$.

(16) Cai, S.; Zhang, D.; Zhang, L.; Huang, L.; Li, H.; Gao, R.; Shi, L.; Zhang, J. Comparative study of $3 \mathrm{D}$ ordered macroporous $\mathrm{Ce}_{0.75} \mathrm{Zr}_{0.2} \mathrm{M}_{0.05} \mathrm{O}_{2-\delta}(\mathrm{M}=\mathrm{Fe}, \mathrm{Cu}, \mathrm{Mn}, \mathrm{Co})$ for selective catalytic reduction of $\mathrm{NO}$ with $\mathrm{NH}_{3}$. Catal. Sci. Technol. 2014, 4, 93-101.

(17) Gao, R. H.; Zhang, D. S.; Maitarad, P.; Shi, L. Y.; Rungrotmongkol, T.; Li, H. R.; Zhang, J. P.; Cao, W. G. Morphology-Dependent Properties of $\mathrm{MnO}_{x} / \mathrm{ZrO}_{2}-\mathrm{CeO}_{2}$ Nanostructures for the Selective Catalytic Reduction of $\mathrm{NO}$ with $\mathrm{NH}_{3}$. J. Phys. Chem. C 2013, 117, 10502-10511.

(18) Si, Z. C.; Weng, D.; Wu, X. D.; Ran, R.; Ma, Z. R. $\mathrm{NH}_{3}$-SCR Activity, Hydrothermal Stability, Sulfur Resistance and Regeneration of $\mathrm{Ce}_{0.75} \mathrm{Zr}_{0.25} \mathrm{O}_{2}-\mathrm{PO}_{4}{ }^{3-}$ Catalyst. Catal. Commun. 2012, 17, 146-149.

(19) Busca, G.; Lietti, L.; Ramis, G.; Berti, F. Chemical and Mechanistic Aspects of the Selective Catalytic Reduction of $\mathrm{NO}_{x}$ by Ammonia over Oxide Catalysts: A Review. Appl. Catal., B 1998, 18, 136.

(20) Lietti, L.; Nova, I.; Forzatti, P. Selective Catalytic Reduction (SCR) of $\mathrm{NO}$ by $\mathrm{NH}_{3}$ over $\mathrm{TiO}_{2}$-supported $\mathrm{V}_{2} \mathrm{O}_{5}-\mathrm{WO}_{3}$ and $\mathrm{V}_{2} \mathrm{O}_{5}-$ $\mathrm{MoO}_{3}$ Catalysts. Top. Catal 2000, 11, 111-122.

(21) Maqbool, M. S.; Pullur, A. K.; Ha, H. P. Novel Sulfation Effect on Low-Temperature Activity Enhancement of $\mathrm{CeO}_{2}$-Added $\mathrm{Sb}-$ $\mathrm{V}_{2} \mathrm{O}_{5} / \mathrm{TiO}_{2}$ Catalyst for $\mathrm{NH}_{3}$-SCR. Appl. Catal., B 2014, 152, $28-37$.

(22) Liu, Z. M.; Zhang, S. X.; Li, J. H.; Ma, L. L. Promoting Effect of $\mathrm{MoO}_{3}$ on the $\mathrm{NO}_{x}$ Reduction by $\mathrm{NH}_{3}$ over $\mathrm{CeO}_{2} / \mathrm{TiO}_{2}$ Catalyst Studied with in situ DRIFTS. Appl. Catal., B 2014, 144, 90-95.

(23) Shan, W. P.; Liu, F. D.; He, H.; Shi, X. Y.; Zhang, C. B. A superior $\mathrm{Ce}-\mathrm{W}-\mathrm{Ti}$ Mixed Oxide Catalyst for the Selective Catalytic Reduction of $\mathrm{NO}_{x}$ with $\mathrm{NH}_{3}$. Appl. Catal., B 2012, 115, 100-106.
(24) Shan, W.; Liu, F.; He, H.; Shi, X.; Zhang, C. Novel CeriumTungsten Mixed Oxide Catalyst for the Selective Catalytic Reduction of $\mathrm{NO}_{x}$ with $\mathrm{NH}_{3}$. Chem. Commun. 2011, 47, 8046-8048.

(25) Li, X.; Li, Y. Selective Catalytic Reduction of $\mathrm{NO}$ with $\mathrm{NH}_{3}$ over Ce-Mo-O ${ }_{x}$ Catalyst. Catal. Lett. 2013, 144, 165-171.

(26) Lee, K. J.; Kumar, P. A.; Maqbool, M. S.; Rao, K. N.; Song, K. $\mathrm{H}$.; Ha, H. P. Ceria Added $\mathrm{Sb}-\mathrm{V}_{2} \mathrm{O}_{5} / \mathrm{TiO}_{2}$ Catalysts for Low Temperature $\mathrm{NH}_{3}$-SCR: Physico-Chemical Properties and Catalytic Activity. Appl. Catal., B 2013, 142, 705-717.

(27) Wang, X. Q.; Shi, A. J.; Duan, Y. F.; Wang, J.; Shen, M. Q. Catalytic Performance and Hydrothermal Durability of $\mathrm{CeO}_{2}-\mathrm{V}_{2} \mathrm{O}_{5}-$ $\mathrm{ZrO}_{2} / \mathrm{WO}_{3}-\mathrm{TiO}_{2}$ Based $\mathrm{NH}_{3}$-SCR Catalysts. Catal. Sci. Technol. 2012, 2, 1386-1395.

(28) Peng, Y.; Qu, R.; Zhang, X.; Li, J. The Relationship between Structure and Activity of $\mathrm{MoO}_{3}-\mathrm{CeO}_{2}$ Catalysts for NO Removal: Influences of Acidity and Reducibility. Chem. Commun. 2013, 49, 6215-6217.

(29) Liu, F. D.; He, H.; Lian, Z. H.; Shan, W. P.; Xie, L. J.; Asakura, K.; Yang, W. W.; Deng, H. Highly Dispersed Iron Vanadate Catalyst Supported on $\mathrm{TiO}_{2}$ for the Selective Catalytic Reduction of $\mathrm{NO}_{x}$ with $\mathrm{NH}_{3}$. J. Catal. 2013, 307, 340-351.

(30) Reddy, B. M.; Lakshmanan, P.; Khan, A. Investigation of Surface Structures of Dispersed $\mathrm{V}_{2} \mathrm{O}_{5}$ on $\mathrm{CeO}_{2}-\mathrm{SiO}_{2}, \mathrm{CeO}_{2}-\mathrm{TiO}_{2}$, and $\mathrm{CeO}_{2}-\mathrm{ZrO}_{2}$ Mixed Oxides by XRD, Raman, and XPS Techniques. $J$. Phys. Chem. B 2004, 108, 16855-16863.

(31) Gao, S.; Chen, X.; Wang, H.; Mo, J.; Wu, Z.; Liu, Y.; Weng, X. Ceria Supported on Sulfated Zirconia as a Superacid Catalyst for Selective Catalytic Reduction of $\mathrm{NO}$ with $\mathrm{NH}_{3}$. J. Collid Interface Sci. 2013, 394, 515-521.

(32) Letichevsky, S.; Tellez, C. A.; Avillez, R. R. d.; Silva, M. I. P. d.; Fraga, M. A.; Appel, L. G. Obtaining $\mathrm{CeO}_{2}-\mathrm{ZrO}_{2}$ mixed oxides by coprecipitation: role of preparation conditions. Appl. Catal., B 2005, $58,203-210$

(33) $\mathrm{Si}, \mathrm{R}$. Urea-Based Hydrothermally Derived Homogeneous Nanostructured $\mathrm{Ce}_{1-x} \mathrm{Zr}_{x} \mathrm{O}_{2}(x=0-0.8)$ Solid Solutions: A Strong Correlation between Oxygen Storage Capacity and Lattice Strain. J. Phys. Chem. B 2004, 108, 12481-12488.

(34) Peng, Y.; Li, J.; Chen, L.; Chen, J.; Han, J.; Zhang, H.; Han, W. Alkali Metal Poisoning of a $\mathrm{CeO}_{2}-\mathrm{WO}_{3}$ Catalyst used in the Selective Catalytic Reduction of $\mathrm{NO}_{x}$ with $\mathrm{NH}_{3}$ : An Experimental and Theoretical Study. Environ. Sci. Technol. 2012, 46, 2864-2869.

(35) Xu, H.; Wang, Y.; Cao, Y.; Fang, Z.; Lin, T.; Gong, M.; Chen, Y. Catalytic Performance of Acidic zirconium-based Composite Oxides Monolithic Catalyst on Selective Catalytic Reduction of $\mathrm{NO}_{x}$ with $\mathrm{NH}_{3}$. Chem. Eng. J. 2014, 240, 62-73.

(36) Yu, J.; Si, Z. C.; Chen, L.; Wu, X. D.; Weng, D. Selective catalytic reduction of $\mathrm{NO}_{x}$ by ammonia over phosphate-containing $\mathrm{Ce}_{0.75} \mathrm{Zr}_{0.25} \mathrm{O}_{2}$ solids. Appl. Catal., B 2015, 163, 223-232.

(37) Christou, S. Y.; Alvarez-Galvan, M. C.; Fierro, J. L. G.; Efstathiou, A. M. Suppression of the oxygen storage and release kinetics in $\mathrm{Ce}_{0.5} \mathrm{Zr}_{0.5} \mathrm{O}_{2}$ induced by $\mathrm{P}, \mathrm{Ca}$ and $\mathrm{Zn}$ chemical poisoning. Appl. Catal., B 2011, 106, 103-113.

(38) Li, X. L.; Li, Y. H. Molybdenum Modified CeAlO ${ }_{x}$ Catalyst for the Selective Catalytic Reduction of $\mathrm{NO}$ with $\mathrm{NH}_{3}$. J. Mol. Catal. A: Chem. 2014, 386, 69-77.

(39) Wu, Z. B.; Jiang, B. Q.j Liu, Y.; Wang, H. Q.; Jin, R. B. DRIFT Study of Manganese/Titania-based Catalysts for Low-temperature Selective Catalytic Reduction of $\mathrm{NO}$ with $\mathrm{NH}_{3}$. Environ. Sci. Technol. 2007, 41, 5812-5817.

(40) Topsoe, N. Y. Mechanism of the Selective Catalytic Reduction of Nitric Oxide by Ammonia Elucidated by in situ on-line Fourier Transform Infrared Spectroscopy. Science 1994, 265, 1217-1219.

(41) Chen, L.; Li, J. H.; Ge, M. F.; Ma, L.; Chang, H. Z. Mechanism of Selective Catalytic Reduction of $\mathrm{NO}_{x}$ with $\mathrm{NH}_{3}$ over $\mathrm{CeO}_{2}-\mathrm{WO}_{3}$ Catalysts. Chin. J. Catal 2011, 32, 836-841.

(42) Jiang, B. Q.; Li, Z. G.; Lee, S. C. Mechanism Study of the Promotional Effect of $\mathrm{O}_{2}$ on Low-Temperature SCR Reaction on Fe$\mathrm{Mn} / \mathrm{TiO}_{2}$ by DRIFT. Chem. Eng. J. 2013, 225, 52-58. 
(43) Chen, L.; Li, J.; Ge, M. DRIFT Study on Cerium-Tungsten/ Titania Catalyst for Selective Catalytic Reduction of $\mathrm{NO}_{x}$ with $\mathrm{NH}_{3}$. Environ. Sci. Technol. 2010, 44, 9590-9596.

(44) Liu, F. D.; Asakura, K.; He, H.; Liu, Y. C.; Shan, W. P.; Shi, X. Y.; Zhang, C. B. Influence of Calcination Temperature on Iron Titanate catalyst for the Selective Catalytic Reduction of $\mathrm{NO}_{x}$ with $\mathrm{NH}_{3}$. Catal. Today 2011, 164, 520-527.

(45) Liu, F. D.; Shan, W. P.; Lian, Z. H.; Xie, L. J.; Yang, W. W.; He, $\mathrm{H}$. Novel $\mathrm{MnWO}_{x}$ Catalyst with Remarkable Performance for Low Temperature $\mathrm{NH}_{3}$-SCR of $\mathrm{NO}_{x}$. Catal. Sci. Technol. 2013, 3, 26992707.

(46) Tsyntsarski, B.; Avreyska, V.; Kolev, H.; Marinova, T.; Klissurski, D.; Hadjiivanov, K. FT-IR Study of the Nature and Reactivity of Surface $\mathrm{NO}_{x}$ Compounds formed after NO Adsorption and $\mathrm{NO}+\mathrm{O}_{2}$ Coadsorption on Zirconia- and Sulfated Zirconiasupported Cobalt. J. Mol. Catal. A: Chem. 2003, 193, 139-149.

(47) Zhang, R.; Zhong, Q.; Zhao, W.; Yu, L.; Qu, H. Promotional effect of fluorine on the selective catalytic reduction of $\mathrm{NO}$ with $\mathrm{NH}_{3}$ over $\mathrm{CeO}_{2}-\mathrm{TiO}_{2}$ catalyst at low temperature. Appl. Surf. Sci. 2014, 289, 237-244. 